\title{
LOAS, ENCOMIOS, JÁCARAS Y OTROS TEXTOS AUTÓGRAFOS DE PÉREZ DE LA FUENTE, EN NÁHUATL Y ESPAÑOL. (A PROPÓSITO TAMBIÉN DE LA LOA INFANTIL DE SOR JUANA, QUE SIGUE PERDIDA)
}

\author{
PRELUDES, TRIBUTES, JIGS AND OTHER AUTOGRAPH \\ TEXTS BY PÉREZ DE LA FUENTE IN NAHUATL AND \\ SPANISH. (AND ON THE LOST LOA WRITTEN BY \\ SOR JUANA AS A CHILD)
}

Miguel Zugasti

TriviUN-Universidad de Navarra mzugasti@unav.es

Resumen: El artículo reivindica la figura de Joseph Antonio Pérez de la Fuente a partir del hallazgo de un manuscrito autógrafo suyo que contiene más de veinte piezas teatrales breves, junto a varias traducciones. Este desconocido dramaturgo, que vivió en la Nueva España de los siglos xviı y xVIII, escribió su obra combinando el náhuatl con el español. Pieza segura suya, de indisputable autoría, es cierta Loa satírica que en 2001 se atribuyó a sor Juana Inés de la Cruz, error que gozó de gran predicamento y que urge desterrar del panorama crítico.

Palabras clave: Joseph Antonio Pérez de la Fuente; teatro breve novo-

hispano; Loa satírica; sor Juana Inés de la Cruz; errores críticos.

ABSTRACT: Based on an autograph manuscript containing more than twenty short theatrical pieces, and several translations, this article recovers an unknown playwright from the XVII and XVIII centuries. Joseph Antonio Pérez de la Fuente lived in New Spain and wrote his works in Nahuatl and Spanish. One piece that is indisputably by Pérez de la Fuente is the Loa satirica, which in 2001 was attributed to sor Juana Inés de la Cruz, an error that has enjoyed critical prestige but must be rectified.

Keywords: Joseph Antonio Pérez de la Fuente; short theater from

New Spain; Loa satírica ('Satirical Prelude'); sor Juana Inés de la

Cruz; critical errors.

Recepción: 6 de julio de 2017; aceptación: 27 de noviembre de 2017.

D.R. ( ) 2018. Nueva Revista de Filología Hispánica Licencia Creative Commons Attribution-NonCommercial (CC BY-NC) 4.0 International 
El presente artículo tiene un doble objetivo: de un lado, reivindicar la figura de Joseph Antonio Pérez de la Fuente y Quijada, dramaturgo, poeta, traductor, gramático, lexicógrafo..., perito en la lengua náhuatl por razón de cuna (era mestizo), que vivió y se movió en la zona de los volcanes (Ayapango, Amecameca, Tlayacapan, Tlalmanalco, San Antonio Zoyatzinco...) en un período todavía sin concretar, pero que como mínimo abarca la segunda mitad del siglo xvir y las dos primeras décadas del siglo XVIII; de otro lado, a la vez que se documenta y pone en realce su figura y obra, hay que concluir de modo categórico que la Loa satírica que en 2001 rescataron del olvido Vallejo Villa y Díaz Cíntora, no es la loa infantil de sor Juana Inés de la Cruz, de cuya redacción tenemos noticia desde 1700 . Esta Loa satírica la escribió, con total seguridad, el citado Pérez de la Fuente en el año 1682. Intentaremos explicar los hechos ajustándonos a una cronología coherente y con sustento archivístico, evitando caer en subjetividades y ofuscamientos, en un empeño por anteponer la fuerza del documento (rescate de un ítem perdido del Museo Boturini) a cualquier apriorismo que mediatice nuestra investigación.

\section{LA LOA INFANTIL DE SOR JUANA}

El primer biógrafo de sor Juana, el jesuita Diego Calleja -con quien parece que se carteó en vida ${ }^{1}$, hablando de la precocidad de la futura literata, desliza el comentario de que alcanzó a escribir una loa sacramental cuando todavía era una niña:

No llegaba a los ocho años la Madre Juana Inés cuando, porque le ofrecieron por premio un libro, riqueza de que tuvo siempre sedienta codicia, compuso para una fiesta del Santísimo Sacramento una loa, con las calidades que refiere un cabal poema. Testigo es el muy reverendo Padre Maestro fray Francisco Muñiz, dominicano, vicario entonces del pueblo de Mecameca, que está

1 Decimos "parece que se carteó", porque hay serias dudas de que el jesuita español Diego Calleja llegara a tener tan fluida correspondencia epistolar con sor Juana como él afirma. Véase al respecto ARIAS DE LA CANAL 1998, pp. 149-151, Schmidhuber de la Mora 1999 y Vallejo Villa 2005. 
cuatro leguas de la casería en que nació la Madre Juana Inés (Calleja 1700, f. III3v).

La Décima Musa no recopiló esta loa infantil entre los papeles personales que envió a la imprenta (o a sus amigos para que los imprimieran), y desde entonces todos los esfuerzos por localizarla han resultado vanos, siendo harto difícil que puedan ser coronados algún día por el éxito. No perdamos de vista que si sor Juana nunca recuperó esa loa infantil sería por algo y tendría sus razones: quizás lo intentó y no pudo porque el texto estaba fuera de su alcance, ya perdido para siempre -lo más probable- en cualquier rincón de Amecameca; pero quizás también porque, desde la altura de su madurez vital y creativa, consideró que esa loa primeriza poco o nada podía añadir a la calidad de su obra y ni se le pasó por las mientes mandar imprimirla.

Recuérdese que en el "Prólogo" al tomo de Fama y Obras póstumas, Juan Ignacio de Castorena y Ursúa afirma que "otros muchos discretos papeles y cartas es sin duda que escribió la poetisa, pero como jamás desvaneció su humildad la esperanza de darlos a las prensas, los despedía hasta en los borradores, y sin dificultad se perdieron" (1700, f. **4r). Si eso hacía sor Juana con su obra de madurez, tampoco cabe esperar que hiciera cosa muy diferente con su loa infantil. El mismo Castorena y Ursúa ofrece jugosos detalles sobre algunos de los textos sorjuaninos que se quedaron sin imprimir: una glosa en décimas a la "ínclita religiosa acción" de Carlos II de "haber cedido el trono a la Divina Majestad Sacramentada"; unas "Súmulas" del puño y letra de sor Juana que poseyó el Padre Joseph de Porras; un "Equilibrio moral" cuyo borrador al parecer estuvo en manos de Sigüenza y Góngora; un "Poema que dejó sin acabar don Agustín de Salazar y perficionó con graciosa propriedad la poetisa, cuyo original guarda la estimación discreta de D. Francisco de las Heras ${ }^{2}$... y se está imprimiendo para representarse a sus Majestades"; otros "Discursos a las finezas de Cristo" diferentes a los conocidos en la Respuesta a Sor Filotea; un "Romance gratulatorio a los cisnes de la Europa que elogiaron

${ }^{2}$ Este Francisco de las Heras que poseyó el autógrafo sorjuanino fue secretario de la virreina Marquesa de la Laguna (la amiga de sor Juana), y seguramente tuvo parte activa en la publicación de Inundación castálida (1689). 
su segundo tomo ${ }^{3}$, y va truncado en este libro" (Castorena y Ursúa 1700, f. **4r).

El buen jesuita implora a los poseedores de estos textos que remitan una copia al impresor y los hagan públicos, cosa que no ocurrió. Con el paso de los siglos se ha recuperado la glosa en décimas a Carlos II (Bryant 1964), se ha identificado el poema escrito de consuno entre Salazar y sor Juana con la tercera jornada de La segunda Celestina (Schmidhuber de la Mora 1990) ${ }^{4}$, han aflorado también unos desconocidos "Enigmas a la Casa del Placer" (Martínez López 1968)..., pero la mayor parte de estos materiales sigue sin aparecer, al igual que sus cartas particulares, el tratado de música citado por Calleja (el Caracol) ${ }^{5}$ o los "quince legajos de escritos, versos místicos y mundanos" que al parecer la monja jerónima dejó en su celda a la hora del tránsito (Trabulse 1999, p. 58). Durante siglos, generaciones de investigadores -sobre todo mexicanos, pero no sólo- han revuelto legajos y acervos mil a la caza de tan codiciados textos.

\section{Un DESCONOCIDO LITERATO LLAMAdo JoSEPH ANTONIO Pérez de la Fuente y Quijada}

Las nunca tranquilas aguas de la crítica sorjuanina se agitaron aún más con el recién estrenado siglo xxi cuando Díaz Cíntora y Vallejo Villa anunciaron que habían descubierto la loa infantil de sor Juana, escrita con partes en náhuatl y español, y la publi-

${ }^{3}$ En referencia al Segundo volumen de las obras de soror Juana Inés de la Cruz, Tomás López de Haro, Sevilla, 1692; o quizás también a cualquiera de las tres reimpresiones que se hicieron al año siguiente en Barcelona, con esta variante en el título que se ajusta más a las palabras exactas de Castorena y Ursúa: Segundo tomo de las obras de Soror Juana Inés de la Cruz, Joseph Llopis, Barcelona, 1693.

4 Salazar y Torres muere en 1675 dejando inconclusa su comedia $L a$ segunda Celestina. La terminó y publicó en España su amigo Juan de Vera Tassis (Cítara de Apolo, 1694). Pero Schmidhuber de la Mora encontró una edición suelta de La gran Comedia de la Segunda Celestina. Fiesta para los años de la Reina nuestra señora, año de 1676, que contiene un tercer acto diferente al anterior. Aunque dicha suelta sólo estampa en la portada el nombre de Salazar y Torres, es posible que el tercer acto sea de sor Juana. La atribución tiene verosimilitud y sustento documental, aunque ni mucho menos es punto pacífico entre la crítica sorjuanina.

5 "Estudió el arte [de la música] muy de propósito, y le alcanzó con tal felicidad, que compuso otro nuevo y más fácil, en que se llega a su perfecto uso sin los rodeos del antiguo método" (CALLEJA 1700, f. IIII[2v). 
caron -en dos artículos complementarios- en el número 34 de la revista Letras Libres, con traducción al castellano de Díaz Cíntora. Aunque salieron a la luz en octubre de 2001, en agosto de ese año ya estaba lanzada una intensa campaña de difusión de la noticia en muchos periódicos, revistas y radios de México e incluso del extranjero (La Prensa, Panamá; El Mercurio, Chile), con reportajes y entrevistas a los citados investigadores (Poot Herrera 2003, pp. 300-311). Si bien no faltaron voces que pedían cautela, transparencia y máximo rigor científico a la hora de exponer el documento recién localizado, en general la idea que perduró fue la de que, en efecto, se había recuperado un texto de sor Juana hasta entonces perdido, texto en náhuatl que se correspondía con la loa infantil de la monja jerónima.

Refutar una propuesta así requiere de mucha más pericia y saber filológicos que el mero hecho de plantearla, y además tal refutación no suele ir acompañada de parejo eco mediático, aunque esto último es secundario para el avance de la ciencia. Es por eso que el artículo de 2003 de Sara Poot Herrera, "Hay loas que no hacen ruido. La hipotética loa infantil de Sor Juana", salió sin tanto estruendo y fue menos leído y divulgado que los dos de Letras Libres. La profesora yucateca, afincada profesionalmente en Santa Bárbara (California), desmontaba el argumentario de Vallejo Villa y Díaz Cíntora y apenas si dejaba un leve resquicio para que la loa de marras fuera de sor Juana, caso de que se presentara documentación fehaciente y veraz, cosa que nunca ocurrió ${ }^{6}$. Con todo y con eso, el supuesto hallazgo siguió ganando adeptos (Fernando Serrano Migallón, Enrique Flores, Margarita Loera...), pues siempre atrae más el deslumbramiento de lo nuevo que el apego a la vieja filología. Sara Poot Herrera tampoco cejó en su empeño y siguió publicando sus asertos -cada vez más contundentes- sobre la pretendida loa infantil de sor Juana en sendos trabajos de 2005, 2007, 2009 y 2009a que consigno en la bibliografía. En 2010 se agregó al club -por así decirlo-Alejandro Soriano Vallés, quien en su libro Sor Juana Inés de la Cruz, doncella del verbo incluye un apartado con este epígrafe: "El primer poema de Juana Inés, aún perdido” (pp. 65-82).

Me interesa destacar ahora cómo de las cinco publicaciones citadas de Poot Herrera, en las dos últimas, ambas de 2009,

6 "Ni fugitivamente se nota la sombra de Sor Juana" (Poot Herrera 2003, p. 320); "Aun así, puede reservarse el derecho de la duda” (Poot Herrera 2005, p. 298). 
empieza a emerger con fuerza un nombre casi desconocido que -lo proclamo- sí es el verdadero autor de la loa satírica mal atribuida a sor Juana: Joseph Antonio Pérez de la Fuente. De él nos dice la profesora que "una vez más veo la necesidad de realizar una amplia investigación de la obra de este poeta, traductor, lingüista, el muy religioso nahuatlato Joseph Antonio Pérez de la Fuente y Quixada" (Poot Herrera 2009, p. 212). Resulta que él es el indubitable creador de un conjunto de loas y encomios escritos mayormente en náhuatl, pero con mezcla ocasional del español, que agrupó bajo el llamativo título de Mercurio encomiástico. Se trata de "una antología poética de loas, encomios, elogios, canciones, versos y jácaras; un ejemplo de teatro religioso en náhuatl y en español a caballo entre el siglo XVII y xVIII cuyas piezas van trazando un interesante y genuino itinerario (con precisión geográfica e histórica) de esta representación teatral religiosa que vuela de pueblo en pueblo" (Poot Herrera 2009, p. 209). Conocemos asimismo que, junto a este ramillete de loas del Mercurio encomiástico, compuso varias obras más de teatro breve y tradujo al náhuatl textos tan heterogéneos como el Catecismo de Ripalda, la Cartilla con sus oraciones y la Gramática (o Arte) de Nebrija (esta última, que él declara inacabada, sigue en paradero desconocido).

Por diversos avisos que Pérez de la Fuente desgrana en sus papeles, sabemos que el 26 de septiembre de 1666 ya había empezado a escribir y traducir textos al náhuatl, tarea a la que se aplicó durante más de medio siglo, pues su último autógrafo tiene la data de 1719: una "Canción a Nuestra Señora de Guadalupe en verso mexicano" que se guarda en la New York Public Library ${ }^{7}$.

Si en 1666 ya acometía tareas literarias, cabe deducir que habría nacido antes de mediar el siglo XviI, quizás en la década de los 40. Carecemos de datos suyos posteriores a 1719, pero por su longevidad es de suponer que no habría sobrevivido muchos años más. Vallejo Villa sugiere que nació "probablemente en la ciudad de Pachuca" (2001, p. 81), aunque no dice en qué se basa. Lo cierto y seguro es que en 1682 ya andaba por la provincia de Chalco (Tlayacapan), y por allí se movió durante el resto de su vida (Ayapango, donde residió y puso escuela de niños, Amecameca, Tlalmanalco, San Antonio Zoyatzinco...).

7 La misma "Canción" aparece en los manuscritos de París y Princeton (véanse, infra, apartados 5 y 6), aunque con fecha de 1708. 

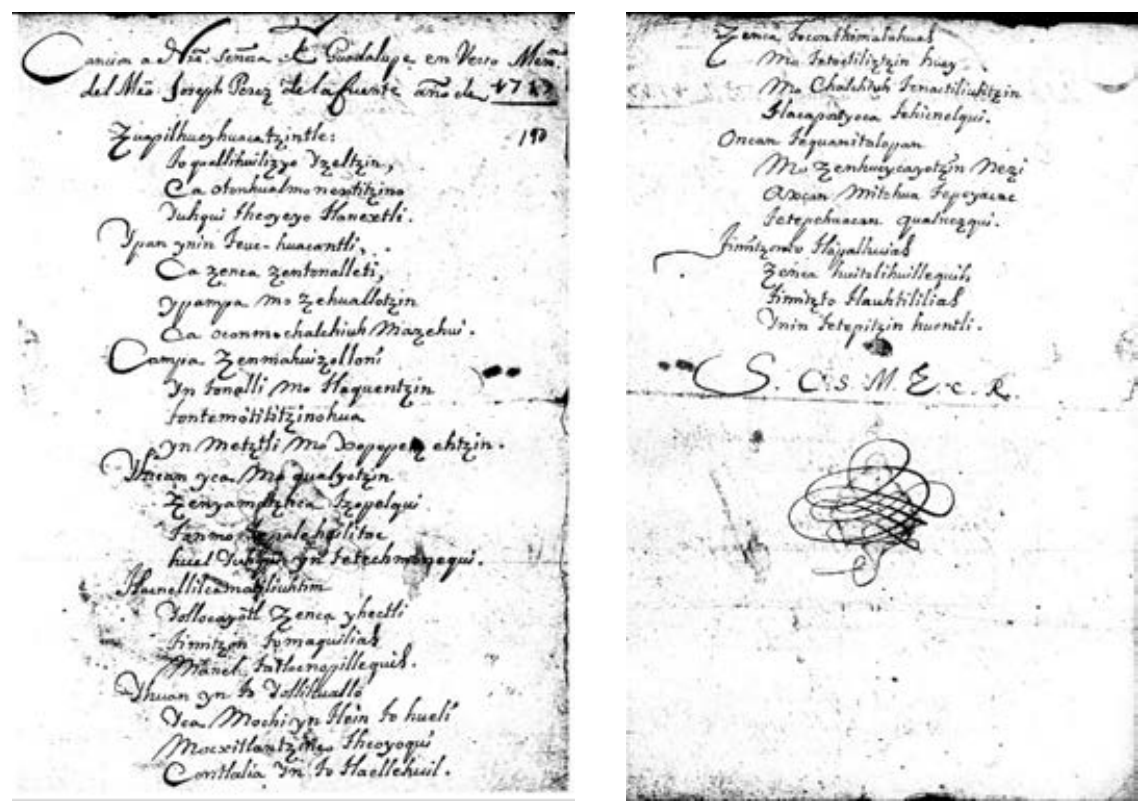

IMÁGENES 1 y 2. Autógrafo completo de la Canción a Nuestra Señora de Guadalupe en verso mexicano, del Maestro Joseph Pérez de la Fuente, año de 1719.

Las gentes de esos lugares lo definen como "mestizo", "chino" o incluso "mestizo achinado", esto es, de rasgos orientales, fiel reflejo del sistema de castas que regía la vida en la colonia. Tuvo al menos un hijo, a quien el 13 de agosto de 1713 dedica una jácara para corregir su mala conducta. De 1693 data un documento conservado en el Archivo General de la Nación sobre "Autos y averiguación en virtud de despacho de los señores Presidente y alcaldes de la Real Audiencia y sala del crimen, contra Don Diego y Don Domingo de Silva, indios, y Joseph Pérez de la Fuente, sobre estar mandados desterrar por Real provisión, ser sediciosos, cavilosos, y que inquietan los pueblos y haciendas de la Provincia” (AGN, Criminal, vol. 227, expediente 9 , ff. 183r-192v $)^{8}$.

En el proceso se denuncia que "Joseph Pérez de Fuentes y Domingo de Silva y don Diego de Silva..., con poco temor de Dios..., traen alborotado dicho pueblo" de Ayapango con malos tratos a los indios naturales, "motivándoles a que entre sí tengan disturbios [y] se maltraten los unos a los otros, de tal suerte que

\footnotetext{
8 Citado por Vallejo Villa 2001, p. 81.
} 


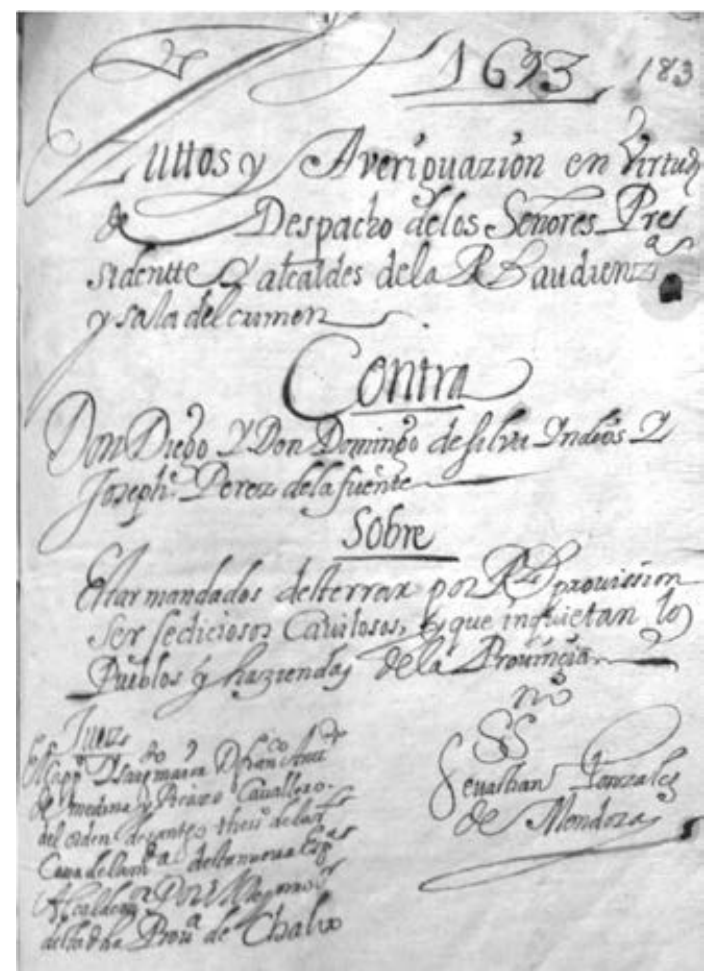

Imagen 3. AGN, Criminal, vol. 227, expediente 9, f. $183 r$.

les incisten [insisten] a que pongan demandas" (f. 184r), por lo cual se pide una Real Provisión de destierro contra los tres citados. Al parecer, el proceso venía de años atrás. Los indios principales don Diego y don Domingo de Silva (padre e hijo) son tachados -desde la oficialidad y el poder, claro- de "inquietos y alborotadores y perjudiciales" y de mover a los indios a solicitar que "quitasen el servicio que daban a los padres del señor San Francisco y a los alcaldes mayores" (f. 186v). Acusados de haberse enriquecido incitando a los naturales a pleitear, un indio principal del pueblo de San Francisco Zentlalpa, llamado don Diego de San Miguel, trajo hacia 1685 una Real Provisión de la Audiencia de México que ordenaba desterrar de la provincia a ambos Silvas (ff. 186v y 190v). En breve plazo muere el citado Diego de San Miguel, de modo que los Silvas se personaron en casa de la viuda "y trasegaron las cajas y escritorios y quitaron la Real Provisión, y la han ocultado hasta hoy" (f. 186v). Si esto aconteció hacia 1685, parece que hasta 1690 no entró en 
acción Pérez de la Fuente, año en que se avecindó en Ayapango, tomando partido en pro de los Silvas. A la altura de 1693 se vuelve a lanzar el proceso contra Diego y Domingo de Silva, implicando ahora también en el mismo a Pérez de la Fuente. Todos los testigos declaran unánimemente en su contra, lo cual resulta sospechoso y es buen indicador de cómo actúa el poder establecido contra ciertos individuos incómodos. Aun así, no sabemos si hubo sentencia y consiguiente destierro. En caso afirmativo tuvo que ser un destierro temporal, pues entre los materiales fechados por nuestro autor hallamos un Encomio para la fiesta de Santiago en Ayapanco (25 de julio de 1692), y el siguiente texto es un Elogio a San Juan Bautista en Tlayacapa (1698).

Entre los testigos llamados a declarar, varios de ellos juraron haber conocido a Pérez de la Fuente:

Ha oído decir que en el pueblo de Ayapango se ha avecindado de tres años a esta parte Joseph Pérez de la Fuente, mestizo, aliado de dichos Silvas, el cual también introduce a los indios pleitos y litigios, haciéndoles peticiones por tener y mantener su conveniencia. Y que tiene por cierto será muy del servicio de Dios nuestro Señor y del Rey nuestro señor, y para la quietud y paz desta provincia y sus pueblos, el que los dichos Don Diego, Don Domingo y José Pérez de Fuente se destierren y salgan desta provincia. Y que lo que lleva dicho y declarado es público y notorio, pública voz y fama, y tiene por cierto dirán lo mismo que este testigo los demás vecinos desta provincia (f. 186r).

Ha oído decir a muchos que en el dicho pueblo de Ayapango se ha avecindado de tres años a esta parte un mestizo o chino llamado Joseph de Fuentes, introduciéndose con los naturales a hacerles peticiones, aconsejándoles pleitos, uniéndose con dichos Cilvas [Silvas], por lo cual sabe y tiene por cierto será muy del servicio de Dios y del Rey nuestro señor, [y para la] paz y quietud de los pueblos y haciendas de la provincia, el que los dichos Don Diego, Don Domingo de Silva y Joseph Pérez de Fuentes se destierren y salgan desta dicha provincia (f. 186v).

Asimesmo sabe este testigo cómo agora ha tres años se [ha] avecin[da]do un mestizo achinado llamado Joseph Pérez de Fuentes, quien les hace escritos y los aconseja e industria, junto con los dichos Cilvas [Silvas], y que ha oído decir públicamente que dicho Joseph Pérez es el motivo y causa principal de que anden alborotados (f. 187r-187v). 
Sabe este testigo que de tres años a esta parte dicho Don Domingo de Silva ha introducido en el pueblo de Ayapango a un mestiso achinado llamado Joseph Pérez de Fuentes, que también es caviloso, y hace las peticiones a los indios y les aconseja y met[e] en pleitos, por lo cual tiene por cierto será muy del servicio de Dios nuestro Señor y de nuestro rey y señor, y para quietud y paz de los pueblos y haciendas desta provincia, el que salga[n] desterrados y fuera della los dichos Don Diego y Don Domingo de Silva, Don Diego Méndez y Joseph Pérez de Fuentes (ff. 189v-190r).

Algo típico de esta clase de pleitos es ver cómo casi todos los declarantes dicen más o menos lo mismo, siguiendo las pautas marcadas del interrogatorio. Aun así, algunos de ellos citan sólo a los indios Diego y Domingo de Silva, sin mencionar a nuestro ilustre mestizo. Otro informante más, a la pregunta de "si sabía o tenía noticia de un mestizo achinado nombrado Joseph Pérez de Fuentes, también alborotador con dichos Silvas", respondió que "no lo conoce ni ha oído mentar" (f. 189r), lo cual se repite con el último testigo, que tampoco lo conoce (f. 192). Más interés tiene para nosotros el penúltimo declarante, quien afirma que nuestro autor regentaba en 1693 una escuela de niños en Ayapango:

Asimesmo sabe cómo en el pueblo de Ayapango, de dos años a esta parte poco más o menos, se [ha] avecindado un mestizo achinado llamado don Joseph Pérez de Fuentes, y que desde que éste entró y se acompañó con los dichos Don Diego de Silva y Don Domingo, [ha] habido alborotos y pleitos y inquietudes en dicho pueblo, introduciendo a pleitos [y] disgustos de todos estos pueblos. Y como tiene escuela el dicho Joseph Pérez de enseñar niños, los introduce y enseña a peticiones y a cómo han de ser relatores, y formando audiencia en dicha escuela, fingiendo pleitos para ello (ff. 190v-191r) $)^{9}$.

Ante el acopio de esta información sobre su vida y obra -si bien todavía en bosquejo-, hay que apresurarse a reconocer que Pérez de la Fuente emerge del olvido como un literato de peso y relevancia inesperados, digno de que se le preste más atención de la que hasta ahora ha gozado. El asombro se apodera de nosotros al observar que no cuenta con una simple entrada

9 Entiendo que Pérez de la Fuente, en su labor pedagógica, fomentaba la oratoria y el debate en el aula, algo muy propio de un enseñante con vocación de dramaturgo. 
en la documentadísima Enciclopedia de México, ni en el Diccionario Porrúa de historia; su nombre tampoco aflora por ningún lado en ciertos recorridos que se han hecho por las literaturas aborígenes (Arias-Larreta, Segala...); ni siquiera Wikipedia sabe de su existencia, aunque es seguro que este injusto vacío acabará por subsanarse (el tiempo me dará la razón). Inútil buscarlo también en cualquiera de los dos volúmenes de Teatro náhuatl (dignos, por otro lado, del máximo elogio) surgidos tras los arduos trabajos de Fernando Horcasitas (1974) y su equipo (2004). Sí aparece su nombre en la Historia de la literatura náhuatl de Garibay (1987, t. 2, pp. 180-181 y 206), siquiera para lamentar la imposibilidad -a la altura de 1954- de acceder a sus textos. Una mención más localizo en la Enciclopedia guadalupana de Xavier Escalada (1995, t. 4, pp. 608-609), donde se dice que fue cura, quizás a partir de una lectura restrictiva de Beristáin, quien apuntó la posibilidad de que fuera "cura, vicario o natural solamente y vecino del pueblo de Amecameca" (Beristáin 1816, t. 1, p. 531). En esta Enciclopedia guadalupana, además, se da la fecha del 27 de abril de 1709 para la composición de la comedia El portento mexicano (inauguración del nuevo santuario guadalupano); se citan como suyos unos Versos mexicanos de Nuestra Señora de Guadalupe, así como la más conocida Relación mercurina; se afirma que Boturini poseyó los manuscritos de todas estas obras.

El colmo de la mala suerte en el cruce de Pérez de la Fuente con la historia se patentiza en el caso de su comedia El portento mexicano, la cual, tras haber pasado trescientos años casi olvidada -digo "casi" porque a mediados del siglo xix ya la había trabajado Faustino Chimalpopoca Galicia ${ }^{10}$, , con la llegada del siglo Xxi le vino la oportunidad de salir a la luz de las prensas. Y por partida doble además, pues en 2004 y 2006 se publican sendas ediciones bilingües (náhuatl-español y náhuatl-inglés), sin contacto entre sí, de El portento mexicano: una con traducción de Horcasitas (al cuidado de Viveros) y otra con traducción de Poole. En honor a la verdad, este último crítico sí baraja la posibilidad de que la comedia sea de Pérez de la Fuente, pero la

10 Añadamos a este "casi" la leve mención al título que hace OlAvarRía y FERRARI, quien en los copiosos tres volúmenes de su Reseña histórica del teatro en México dedica a nuestro autor una línea y media: "D. José Antonio Pérez de la Fuente con su comedia El portento mexicano y veinte loas en verso mexicano" (1895, t. 1, p. 32). 
desecha y opta por la anonimia (Poole 2006, pp. 23-25) ${ }^{11}$. Así es que, al final, ninguna de las dos ediciones otorga la autoría a Pérez de la Fuente y la obra queda como anónima ${ }^{12}$.

\section{Obras de Pérez de la Fuente en el Museo Boturini}

La figura de Lorenzo Boturini (1698-1755) resulta clave para la transmisión de la obra manuscrita de Pérez de la Fuente. Boturini pasó ocho años en México (1736-1743), y durante los siete primeros se dedicó a recopilar, comprar o encargar copias de cualquier documento que tuviera que ver bien con el culto a la Virgen de Guadalupe, o bien con la historia antigua de México (Flores Salinas 1966, pp. 17-33; El caballero Lorenzo Boturini 2010). Parece asimismo que, con tal propósito, aprendió algunas nociones de náhuatl. La suya fue, sin duda, la mayor colección documental jamás reunida sobre México, adquirida -según sus propias palabras- tras "siete años de pesadísimos trabajos, muchas enfermedades y cantidad crecida de dinero" (Flores Salinas 1966, p. 20). Poseyó documentos que antes habían pertenecido a personajes tan relevantes como Fernando de Alva Ixtlilxóchitl y Carlos de Sigüenza y Góngora. Su empeño por difundir el culto guadalupano y coronar a la Virgen, siendo como era un civil, y además extranjero, generó graves suspicacias en ambos poderes, el civil (virrey) y el religioso (J.A. Vizarrón, arzobispo de México). Así, el 4 de febrero de 1743, el recién llegado virrey, conde de Fuenclara, confisca su valiosa colección (el llamado "Museo Boturini") y lo encarcela. Meses después, estando recluido en la Cárcel Real de México, entre los días 16 y 28 de septiembre de 1743, se levantan un total de ocho inventarios de los papeles y documentos existentes en su colección personal. Boturini asienta ante escribano sus objetos más valiosos (manuscritos, libros, mapas, pinturas, dibujos, cartas, códices...), pero lo hace de memoria, sin que se le permitiera volver a su casa

11 Otros críticos, como Garibay (1987, t. 2, pp. 134 y 206), Arrom (1967, p. 73) o BRINCKMANN (1978, p. 165), apoyándose en Boturini y Beristáin, dieron por buena la autoría de Pérez de la Fuente. En la misma línea se posiciona BURKHART: "I am also assuming that the author of El portento mexicano was Joseph Pérez de la Fuente, as is indicated in the BNF manuscript" (2006, p. 32).

12 Poot Herrera (2009a, pp. 372-375) ya hizo notar también esta lamentable coincidencia. 
y tenerlos a la vista. A nosotros nos interesa destacar ahora este dato extraído del octavo y último inventario, ítem 32:

Historia genuina de las mismas apariciones de la misma Sra. [la Virgen de Guadalupe] en lengua mexicana, y otra traducida en romance, con una comedia mexicana, del mismo asunto, loas y versos en mexicano, anexa a unas obras mercurinas que compuso en lengua mexicana José Antonio Pérez de la Fuente, todas dignas de imprimirse, por el primor con el cual el autor las expende (manifiesta) en el elegantísimo idioma mexicano, en fojas setenta y nueve (Peñafiel 1890, t. 3, p. 66) ${ }^{13}$.

He aquí un dato interesantísimo y muy temprano (28 de septiembre de 1743) de cómo Boturini poseía 79 hojas manuscritas a nombre de José Antonio Pérez de la Fuente, con distintas obras compuestas por él, de las cuales se afirma que es su autor, no un simple copista. Aquí están ya las loas escritas en náhuatl y otras piezas mercurinas. El proceso contra Boturini dio un giro radical el último trimestre de 1743: se le declara inocente, pero no se le devuelven sus objetos confiscados; se considera que su estancia en México es ilegal y a fines de año es deportado a España. En Madrid consigue que el Consejo de Indias lo absuelva de todos los cargos y lo recomiende para el nombramiento de "Historiador de las Indias"; traba amistad con un criollo mexicano llamado Mariano Fernández de Echeverría y Veytia, quien lo ayuda a establecerse en la corte. Jamás recuperó su colección, pero es el caso que, haciendo uso de una memoria prodigiosa, o quizás con el auxilio de apuntes propios o de alguna copia del inventario hecho en México, el rehabilitado Boturini publica en 1746 su obra más importante: Idea de una nueva historia general de la América septentrional. Fundada sobre material copioso de figuras, simbolos, caracteres y geroglíficos, cantares y manuscritos de autores indios últimamente descubiertos, Juan de Zúñiga, Madrid ${ }^{14}$.

13 Peñafiel transcribió el contenido de los ocho inventarios: 1890, t. 3, cap. 12, "Monumentos escritos", pp. 56-68. La obra de Peñafiel, por su tamaño y antigüedad, resulta de difícil acceso, pero tales inventarios los reeditó más tarde Flores Salinas (1966, “Apéndice 1”, pp. 127-186).

${ }^{14}$ Manejo la edición príncipe que está en línea (http://bvpb.mcu.es/ es/ consulta/ registro.cmd?id=406186), pero hay ediciones modernas en México: Porrúa, prólogo de M. León-Portilla, 1974 (reed. 1986 y 2007); UNAM, ed. M. Ballesteros, 1990; y por último, una edición facsímil, Instituto Nacional de Antropología e Historia-CONACULTA, 1999. 


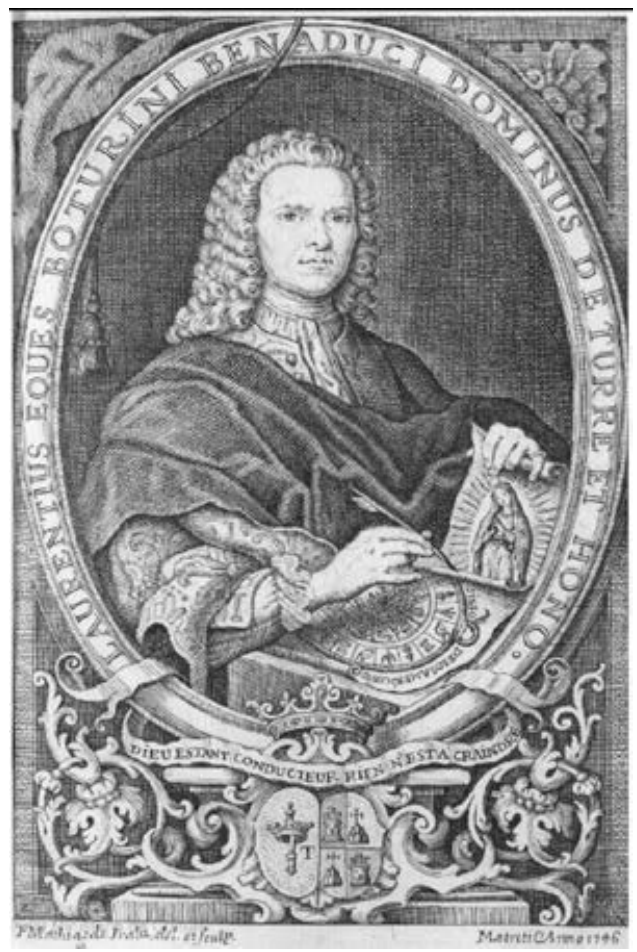

Imagen 4. Retrato de Boturini (Madrid, 1746). Grabado de Matías de Irala.

Este libro contiene al final un largo

Catálogo del museo histórico indiano del caballero Lorenzo Boturini Benaduci, señor de la Torre y de Hono, quien llegó a la Nueva España por febrero del año 1736 y, a porfiadas diligencias e immensos $[s i c]$ gastos de su bolsa, juntó en diferentes provincias el siguiente tesoro literario que va especificado, y dividido según los varios asuntos de las naciones e imperios antiguos de los indios. Y puede servir para ordenar y escribir la historia general de aquel Nuevo Mundo, fundada en monumentos indisputables de los mismos indios.

El catálogo tiene paginación diferenciada de la propia del libro. En las pp. 48-50 de dicho "Catálogo", cap. 24, núms. 2, 3 y 5 , se registran las siguientes obras de Pérez de la Fuente que le fueron desposeídas de su biblioteca ${ }^{15}$ :

15 Boturini repite la llamada a estas mismas obras, de manera más escueta, en el cap. 35, núm. 8, p. 87 del "Catálogo". 


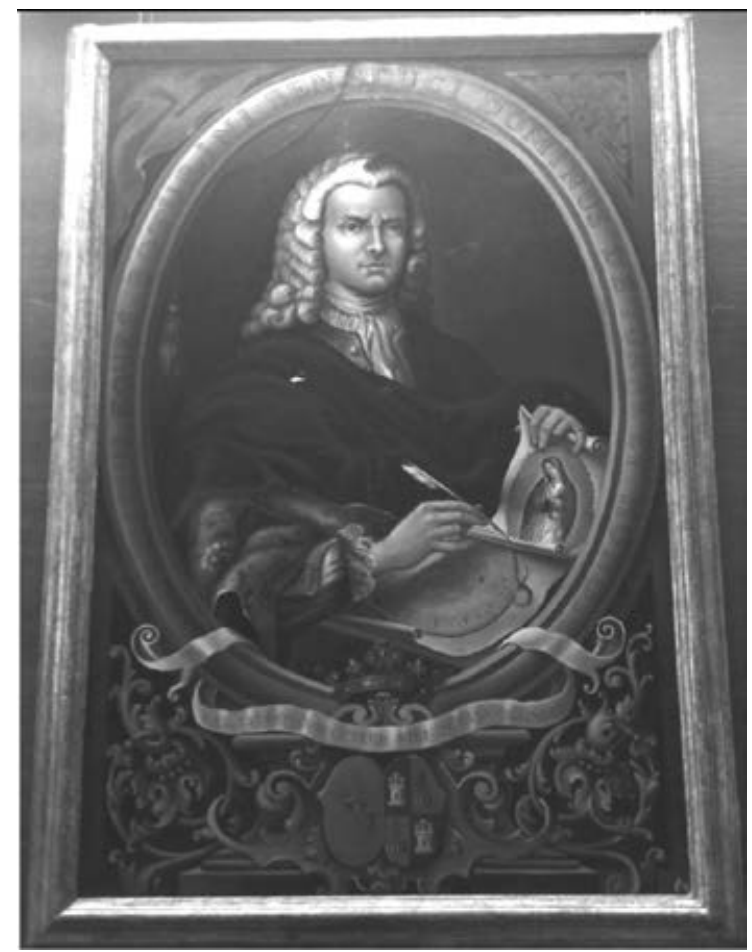

Imagen 5. Retrato de Boturini en la Biblioteca Nacional de Antropología, México.

- Maestro genuino del elegantísimo idioma náhuatl, en 36 fojas de papel europeo. Esto es, la gramática de dicho idioma que compuso don Joseph Antonio Pérez de la Fuente. Fáltale algo del fin.

—Cartilla mexicana y castellana del mismo autor, en 12 fojas de papel europeo.

-Diversas obras en dichas dos lenguas y papel europeo, y algunas en la sola lengua náhuatl, de dicho Pérez. Hállanse en un libro en folio de 19 fojas, y son las siguientes:

1. Relación de la admirable aparición de Nuestra Señora de Guadalupe, en las dos lenguas, castellana y mexicana.

2. Interrogatorio para confesar a los indios mexicanos, en dichas dos lenguas.

3. Práctica de ayudar a bien morir, recopilada del ritual romano. Está en lengua náhuatl.

4. El portento mexicano. Comedia en verso mexicano de la aparición de Nuestra Señora de Guadalupe.

5. El día festivo del alma, sacado de varios autores y traducido en el idioma mexicano. 
6. Mercurio encomiástico, esto es, 20 loas en verso mexicano a diversos propósitos.

7. Borradores devotos. Contienen varias oraciones del Santísimo Rosario, y otras muchas.

8. Versos mexicanos de Nuestra Señora de Guadalupe.

9. Sacra Filomena que discanta en el idioma mexicano los misterios del Santísimo Rosario.

10. Consideración de la Santísima Trinidad, en la misma lengua.

11. La Cartilla con todas sus oraciones, en la misma lengua.

Como bien se puede apreciar, el caudal de la obra de Pérez de la Fuente ha crecido aquí de forma considerable. Se hicieron más inventarios de los papeles de Boturini: uno tempranero en 1745-1746 (supervisado por Patricio Antonio López, publicado en 1925), otro en 1791 (publicado por Vicente de la Rosa y Saldívar, 1946 y 1947), otro en 1804 (al cuidado de Ignacio de Cubas), dos más en 1823, otro en 1917-1918 (publicado por Ramón Mena en 1923), etc., etc. ${ }^{16}$ A nuestros efectos, lo que interesa resaltar es que la obra manuscrita de Pérez de la Fuente está sobradamente registrada en la colección Boturini ${ }^{17}$. La pregunta obligada es: si Boturini nunca recuperó sus papeles y éstos permanecieron en México, ¿cuál fue su paradero?, ¿dónde están ahora? La respuesta es compleja, pues su colección se dispersó bastante. Flores Salinas afirma que "la colección, o partes de ella, estuvieron en varias épocas en el Convento Grande de San Francisco de México, en la Secretaría del Virreinato y en la Universidad" (1966, p. 28). Una parte de los materiales se quedó en México al resguardo del Museo Nacional de Antropología,

16 Datos más precisos en Boban 1891, t. 1, p. 44, Flores Salinas 1966, p. 28, y GLASS 1968, pp. 1-7.

17 No vamos a repetir -por tediosos y cansinos- todos los registros, coincidentes en lo esencial con el de 1743. Baste con esta referencia del inventario de 1745-1746, donde se detalla lo siguiente: "Inventario $8^{\circ}$, núm. 32: En este legajo se halla una relación sucinta de la milagrosa Aparisión de Nuestra Señora de Guadalupe en lengua mexicana, traducida en lengua española con una instrucción para confesar indios mexicanos, una comedia sobre la misma aparisión y otros diferentes versos en el mismo idioma. Su título: Relación mercuriana. Uno y otro manuescripto, y en 79 folios" (López 1925, p. 50). Reproduzco, a título de curiosidad, el siguiente ítem: "Ésta es otra comedia o coloquio a la misma aparición, y una representación en verso a la Pasión de Cristo Señor nuestro que solían los indios hacer por las Cuaresmas, en forma también de coloquio que entre ellos llaman NIZCUITILE, uno y otro en treinta y cuatro folios" (López 1925, p. 50, núm. 33). 
el Archivo Histórico del Instituto de Antropología e Historia, la Biblioteca Nacional y la Basílica de Guadalupe, cuya biblioteca lleva el nombre de Boturini; pero otra parte -quizás la mayorfue víctima del expolio y la venta entre particulares:

Es posible que antes de 1800, gran parte de la colección haya pasado a manos de Antonio de León y Gama y del padre José Pichardo, así como de [Mariano Fernández de Echeverría y] Veytia. Quizá entendidos coleccionistas como Jean Frederick Waldeck y Joseph Marius Alexis Aubin hayan conseguido numerosos ejemplares de descendientes o parientes de aquellos entendidos historiadores (Flores Salinas 1966, pp. 28-29).

El "quizá" de la última frase es un simple giro retórico, pues es bien sabido que todos los personajes citados, y muchos otros (casos de Alejandro von Humboldt o José Fernando Ramírez), poseyeron alguno de estos documentos ${ }^{18}$. De la referida nómina descuellan los nombres de Pichardo y Aubin. Juan José Pichardo (1748-1812), que dominaba tanto las lenguas clásicas como el náhuatl, tuvo acceso al Museo Boturini (el llamado Museo indiano), bien sea directamente o bien sea a través de Echeverría y Veytia (1718-1780). Es posible que adquiriera o se quedara con parte de esos materiales, pero sí sabemos con certeza que copió de su puño y letra muchos papeles de Boturini antes de que se acelerara su ya irremediable proceso de dispersión: tal, por ejemplo, ciertos códices de su Cuernavaca natal, y por supuesto también las obras que nos ocupan de Pérez de la Fuente.

El padre Pichardo (de la congregación de San Felipe Neri) muere en 1812 tras haber rendido un último servicio al poder virreinal fijando los límites entre Louisiana y Texas, obra de más de 3000 folios que concluyó pocos meses antes de su deceso. Lo más probable es que sus familiares o herederos se quedaran con su valioso legado (unos 6000 documentos), incluidos por supuesto los derivados del Museo Boturini (Martínez Marín 1994, p. 14). De sus manos los adquirió el paleógrafo

18 En 1884 decía esto Alfredo Chavero: "Gran parte de sus manuscritos existen en París en poder de monsieur Aubin; algunos hay en nuestro Archivo General, y varios muy interesantes, entre ellos los relativos a la Virgen de Guadalupe, fueron míos; los demás se han perdido por la incuria con que se han visto siempre los preciosos anales de nuestra historia patria" (apud Boban 1891, t. 2, p. 102). 
y coleccionista francés Joseph Marius Alexis Aubin durante la década que pasó en México (1830-1840): del total de sus adquisiciones, al menos una treintena de manuscritos procedían de Pichardo (Boban 1891, t. 2, pp. 225-237 y 443-456) ${ }^{19}$, una veintena larga de Antonio de León y Gama (Boban 1891, t. 2, pp. 457-480) y siete más de Mariano Veytia (Boban 1891, t. 2, p. 383). Los tres, como se ha dicho, antiguos poseedores de partes troceadas del Museo Boturini. En 1840, Aubin se llevó clandestinamente a Francia todo este rico material. En 1889, en el contexto de la exposición universal de París, contactó con otro anticuario y coleccionista llamado Eugène Goupil (aunque de nacionalidad francesa, había nacido en México, hijo de francés y mexicana), a quien le vendió todo su patrimonio. Goupil sumaba esta compra a la que él mismo había hecho un año antes (1888) a otro anticuario francés llamado Eugène Boban. Es de relevancia este último dato porque Goupil encargó a Boban que hiciera un detallado catálogo de sus fondos, el cual se publicó en 1891, en dos tomos (y otro más que contenía un atlas), con este título:

Documents pour servir à l'histoire du Mexique. Catalogue raisonné de la collection de M. E. Eugène Goupil (ancienne collection J. M. A. Aubin). Manuscrits figuratifs et autres sur papier indigène d'agave mexicana et sur papier eurepéen antérieurs et postérieurs a la conquête du Mexique (XVI siècle). Deux volumes de texte accompagnés des portraits du chevalier Lorenzo Boturini et de M. Aubin et d'un Atlas de quatre-vingts planches en phototypie, Paris, Ernest Leroux, 1891, 2 vols.

El hecho de mencionar a Boturini en la portada refleja a las claras cómo Boban-Goupil conocían a la perfección la procedencia de buena parte de los materiales inventariados; se reproduce además el grabado madrileño de Boturini (Imagen 4) y se traza una detallada reseña de su vida (t. 1, pp. 31-51) ${ }^{20}$. En el segundo volumen de estos Documents pour servir à l'histoire du Mexique, núm. 303, pp. 452-453, localizamos la Relación Mercurina

19 "La collection Goupil compte un grand nombre de manuscrits originaux du Père José Pichardo, de copies faites par lui et de cartes géographiques destinées a accompagner ces travaux. On les trouvera dans ce catalogue sous les numéros: 88, 89, 164, 165, 166, 170, 246bis, 287, 288, 289, etc., a 310" (BobAn 1891, t. 2, p. 242).

${ }^{20}$ Se trata de una traducción al francés a partir de una noticia original de Alfredo Chavero, 1884. 
de la aparición de Nuestra Señora la Virgen María de Guadalupe en la lengua mexicana genuina y traducida en castellano, por Dn. Joseph Pérez de la Fuente en Amecameca, a 6 días del mes de mayo 1712 años. A continuación se especifica que es "copie du Père Pichardo" y que se trata de un manuscrito compuesto por once cuadernos de tamaño folio, con un total de 222 páginas $^{21}$. Más abajo describiré en detalle su contenido (apartado 5); baste por ahora con decir que éste se ajusta en lo esencial a lo descrito por Boturini en su "Catálogo", cap. 24, núms. 2, 3 y 5.

Eugène Goupil muere en 1895, cuatro años después de la publicación de estos volúmenes, pero deja instrucciones muy claras a su esposa para que casi todos sus ricos fondos sean donados a la Biblioteca Nacional de Francia (1898), donde permanecen hoy en día ${ }^{22}$. La parte etnográfica fue a parar al Museo de Trocadéro, mientras que la parte bibliográfica se custodia en la sede Richelieu de la BNF. Al poco de recibir los materiales, la BNF los reunió y clasificó en la "Collection Goupil-Aubin", publicando asimismo un Catalogue des manuscrits mexicains de la Bibliothèque Nationale, bajo la responsabilidad de Henri A. Omont (1899). Salvo unos pocos manuscritos que se consignan al final porque no pertenecen a dicho fondo (núms. 385-401), todas las demás entradas (núms. 1-384) provienen de la donación de Goupil. Este catálogo es mucho más simple y sucinto que el de Boban ${ }^{23}$, y secunda además la numeración en arábigos que él puso a cada uno de los ítems, lo cual es importante señalar porque es la misma numeración que rige hoy todavía en el catálogo de la BNF. Así pues, desde Boban, pasando por Omont, el manuscrito "Mexicain 303" se corresponde con la copia a mano que hizo el padre Pichardo de las obras de Pérez de la Fuente; copia sacada de un original que poseyó Boturini y que le fue arrebatado; copia que se llevó Aubin a Francia en 1840 y que desde entonces ha sido el único testimonio conocido

${ }^{21}$ Esta cifra de 222 páginas ha desconcertado a más de un bibliógrafo o catalógrafo, como es el caso de Jiménez Moreno (1939, p. 28). En realidad estamos ante una simple errata, pues no son 222 páginas, sino 252, esto es, 126 folios escritos por ambas caras.

${ }^{22}$ Otros fondos suyos, con libros e impresos varios, se vendieron públicamente en París el 4 de febrero de 1899 (Goupil 1899).

${ }^{23}$ Sin embargo, corrige el error de las 222 páginas que Boban atribuía al manuscrito 303 (el de Pérez de la Fuente), fijando ahora los correctos 126 folios (OMONT, p. 47). 
que ha preservado los escritos en náhuatl y español de Pérez de la Fuente. Hasta ahora. Hasta el reciente hallazgo en Princeton del autógrafo de Pérez de la Fuente, pieza auténtica -ésta síque perteneció al Museo Boturini o Museo indiano, asunto del que me ocuparé más adelante (apartado 6).

\section{Breve fortuna de Pérez de la Fuente en México}

Ya hemos visto cómo pasó la obra de Pérez de la Fuente a Francia merced a la copia manuscrita de Pichardo. El manuscrito autógrafo seguía en tierras mexicanas y generó traslados parciales, como las tres loas que a mediados del siglo XIX (h. 1849-1860) copió Faustino Galicia ${ }^{24}$. En efecto, el Archivo Histórico de la Biblioteca Nacional de Antropología e Historia (INAH) custodia unos "Documentos Históricos del Lic. Faustino Galicia Chimalpopoca" (colección antigua, vol. 254) que contienen múltiples cuadernos, notas, apuntes, dibujos a color (indios, plantas, mapas), traducciones... de este erudito nahuatlato ${ }^{25}$. Entre ellos localizamos dos ítems que nos atañen:

Fojas 230-237: cuadernillo tamaño cuarto, con hojas rayadas en azul y rojo, que contiene la Loa satírica en una comedia en la fiesta del Corpus hecha en Tlayacapa, 1682. En las fojas 232-235 se copia la loa completa en tinta china y debajo de cada verso se escribe a lápiz la traducción de las palabras en náhuatl. En las fojas 236-237 se vuelve a copiar la loa, esta vez sólo en tinta negra, y se incluye lo que parece ser la traducción definitiva pasada a limpio, aunque esta segunda copia sólo alcanza los 64 primeros versos. Es de notar que para Faustino Galicia, el personaje que declama la loa asume el género masculino (no el femenino, como hacen Díaz Cíntora y Maruri Carrillo): "Muy vergonzoso vengo yo" (v. 1), "muy bien encorvado" (v. 4), etcétera.

${ }^{24}$ Faustino Chimalpopoca Galicia (1805-1877) fue un reputado historiador y nahuatlato, autor de obras como el Silabario de idioma mexicano, el Epítome o modo fácil de aprender el idioma náhuatl o lengua mexicana, así como de numerosos Anales mexicanos compilados por José Fernando Ramírez y finalmente publicados por Vargas Rea.

${ }^{25}$ Detallada descripción en Sepúlveda y Herrera 1992, esp. pp. 28-29. 


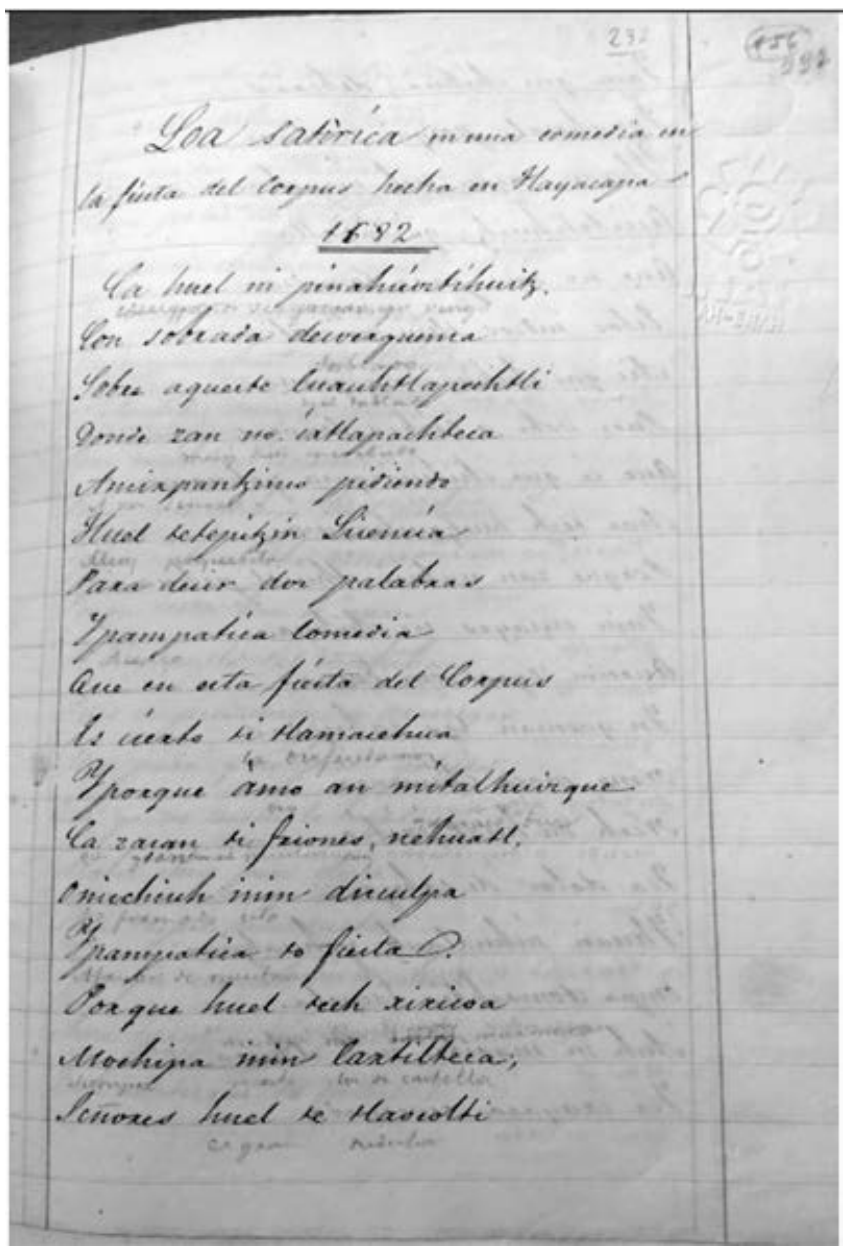

IMAgen 6. Biblioteca del INAH, Archivo Histórico, vol. 254: Loa satírica (1682), copia de Faustino Galicia, foja $232 r$.

Foja 238, tamaño folio, que copia el Mercurio encomiástico en la excelentísima lengua náhuatl hechas con diversos tiempos desde el año de 1682 que en Tlayacapan me hizo hacer D. Juan Hipólito Cortez Quetzalquauhtli y Tequantepehua este Encomio al Santísimo Sacramento ${ }^{26}$. Podría decirse que la intención inicial de don Faustino Galicia fue trasladar todo el Mercurio encomiásti-

26 Agradezco a doña Diana García Pozos, jefa del Servicio al Público de la Biblioteca Nacional de Antropología e Historia de México, las facilidades otorgadas para la consulta de este material. 




Imagen 7. Biblioteca del INAH, Archivo Histórico, vol. 254: Loa satírica (1682), copia de Faustino Galicia, foja $236 r$.

co, pero sólo alcanzó a copiar el Encomio número 1, la Loa número 2 (sin las variantes de las loas 3 y 4 ) y apenas los 14 primeros versos de la Loa número 5. Todo ello en náhuatl, sin emprender la tarea de traducción al castellano. En contra de su costumbre, no hace constar la fecha del trabajo. No hay duda de que el modelo para la copia fue el autógrafo de Pérez de la Fuente (ver infra, apartado 6), décadas antes de que saliera de México definitivamente. 


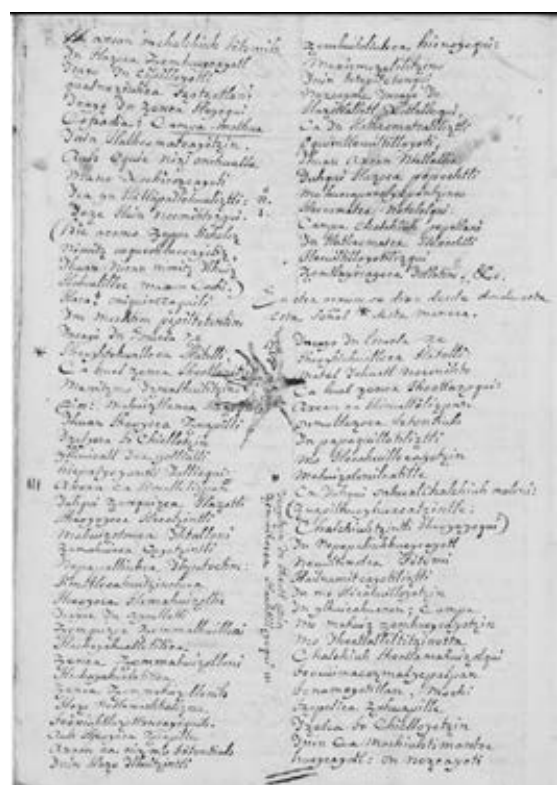

IMAGEN 8. Firestone Library, $m$ s.

C0744.02, f. 183v: Mercurio encomiástico, loas 2 y 3 , autógrafo de Pérez de la Fuente.

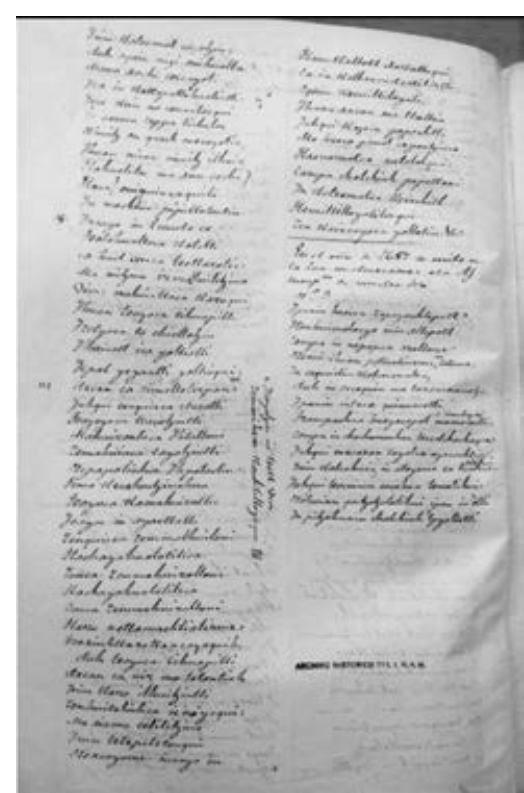

IMAGEN 9. Biblioteca del INAH, Archivo Histórico, vol. 254: Mercurio encomiástico, loas 2 y 3, foja $238 v$, copia de Faustino Galicia.

Pero antes incluso de saltar al siglo xix, en el último cuarto del siglo XVIII, un ilustrado como Joaquín Granados lo cita con gran respeto en sus Tardes americanas (1778):

Quien leyere la Cartilla mexicana y castellana, Maestro genuino del elegante idioma náhuatly Gramática en dicha lengua de don Joseph Pérez de la Fuente, no sólo admirará que es esta lengua más elegante y expresiva que la latina y dulce que la toscana, sino que se veerá precisado a darle a los estudios de su autor los mismos elogios que justamente se han granjeado los Nebrijas y Euforniones (p. 401).

Granados, cuyo libro lo protagonizan un indio y un español, salpica su texto de voces en náhuatl y es seguro que adquirió alguna noción de dicha lengua; de ahí la pertinencia de elogiar a Pérez de la Fuente en su faceta como gramático (comparable a Elio Antonio de Nebrija y a Eufornión), aunque nada diga de él como dramaturgo o poeta. Una nueva referencia -quizás la más conocida de todas- la localizamos en la Biblioteca 
hispano-americana septentrional de Beristáin de Souza, cuyo primer volumen se publicó en 1816 (primera edición: 3 ts., 1816, 1819 y 1821; segunda edición: 3 ts., 1883; tercera edición muy aumentada: 5 ts., 1947). Este insigne bibliógrafo, a la altura del apellido "Fuente" (p. 531), identifica así a nuestro escritor:

Fuente (D. José Antonio Pérez) Cura, vicario o natural solamente y vecino del pueblo de Amecameca, en el arzobispado de Mégico, peritísimo en la lengua megicana y bien instruido en las Bellas Letras. Escribió a principios del siglo 18 lo siguiente:

1. El Maestro genuino del elegantísimo idioma náhuatl.

2. Cartilla megicana y castellana.

3. El portento megicano: Comedia de la Aparición de Nuestra Señora de Guadalupe, en lengua megicana.

4. Día festivo del alma, en el mismo idioma.

5. Mercurio encomiástico: o veinte loas en verso megicano a diversos asuntos.

6. Sacra Filomena: o los Misterios del Rosario en verso megicano.

7. Consideración de la Santísima Trinidad en megicano.

8. El Arte de Nebrija en megicano.

9. El Catecismo de Ripalda en megicano.

10. El Arco Iris del P. Ulloa en megicano.

11. Los Oficios del Santísimo Sacramento y del Patriarca S. José en megicano.

Hacen mención de estos manuscritos el caballero Boturini en su Museo, y el curioso y muy piadoso D. Francisco Sedano en su copiosa colección de Opúsculos guadalupanos ${ }^{27}$. Este sujeto, en el Tom. T de dicha Colección, copia, traducida al castellano, la siguiente [obra] de nuestro Fuente: Relación mercurina de la admirable Aparición de la Virgen María de Guadalupe, escrita en megicano, y firmada en Amecameca a 6 de mayo de 1712. Comienza: "Venía llegando el venturoso Juan Diego al Cabo-cerros, o Cerro Nariz (Tepeyacac)..." (Beristáin 1816, t. 1, p. 531) ${ }^{28}$.

Poco más tarde, José Miguel Guridi también se acuerda de Pérez de la Fuente en su Apología de la aparición de Nuestra Señora

27 Francisco Sedano (México, 1742-1812) fue mercader de libros y por lo tanto no sorprende que tuviera acceso directo a algún manuscrito de Pérez de la Fuente. Al morir, donó sus papeles a su amigo José Mariano Beristáin de Souza, quien los aprovechó ampliamente, como se ve. Su obra más conocida, Noticias de México, se publicó de forma póstuma en 1880.

${ }_{28}$ Cito por la primera edición de la Biblioteca hispano-americana septentrional. La información se mantiene inalterable en ediciones posteriores, todas ellas póstumas. 
de Guadalupe: "D. José Antonio Pérez de la Fuente en 1712 escribió en mejicano y castellano la Historia de Nuestra Señora de Guadalupe, y en mejicano solamente unas loas, una comedia y varios devocionarios" (Guridi 1820, pp. 158-159). El siguiente en nuestra lista es Augustino (Agustín) de la Rosa, quien se apega a Beristáin y en su Dissertatio historico-thelogica de apparitione B.M.V. de Guadalupe (1887) cita tres textos de Pérez de la Fuente: la Relación de la admirable aparición de Nuestra Señora de Guadalupe (1712), un "Drama sacrum de eadem re mexicanis versibus" y unos "Mexicana Carmina de eadem re", para acabar diciendo que "haec tria opera apud se habuit Boturini" (De la Rosa 1887, p. 170). En la misma línea se inscribe Fortino Hipólito Vera y su Tesoro guadalupano. Noticia de los libros, documentos, inscripciones, etc., que tratan, mencionan o aluden a la aparición y devoción de Nuestra Señora de Guadalupe, quien, tras las huellas del Catálogo de Boturini y de la Biblioteca de Beristáin, tampoco se olvida de citar la Relación mercurina ni algún otro texto más de Pérez de la Fuente (Vera 1889, pp. 393-394).

Con el salto al siglo xx cambia por completo la perspectiva. Francisco del Paso y Troncoso, que había sido director del Museo de Antropología de México en dos ocasiones (18891890 y 1891), fue comisionado en 1892 para viajar a Europa y recopilar toda la documentación posible sobre la historia del México antiguo. En Europa pasó los veinticuatro últimos años de su vida (nunca regresó a su país natal; murió en Florencia en 1916) investigando y fotografiando fondos en Oxford, Madrid, Florencia, París, Londres... Tras su muerte, superados no pocos azares, las cajas con sus fotografías, microfilms... llegaron por fin a México. En 1938, Silvio Zavala inventarió con sumo detalle su contenido (junto a la transcripción de docenas de cartas) en un libro titulado Francisco del Paso y Troncoso: su misión en Europa, 1892-1916. Ni que decir tiene que la parisina "Collection Goupil-Aubin" fue uno de los acervos de donde más materiales extrajo Francisco del Paso y Troncoso. He aquí que, casi un siglo después de que Aubin se llevara de México su copiosa colección (1840) con piezas de Boturini, sobre todo, pero también de Veytia, León y Gama, el padre Pichardo..., casi un siglo después, digo, esas mismas obras volvían a México; no las originales, claro, pero sí al menos detalladas fotografías y microfilms.

Entre toda esa masa documental, en silencio y con total discreción, los escritos de Pérez de la Fuente retornaban a su país de origen en busca de una segunda oportunidad -también 
fallida- para darse a conocer. Así es que cuando acudimos al citado libro de Zavala, Francisco del Paso y Troncoso: su misión en Europa, 1892-1916, en la sección de "Documentos relacionados con las gestiones hechas -después de la muerte del señor del Paso y Troncoso- para que sus libros y manuscritos se enviaran a México", en la página 273, paquete 20, localizamos nuestra vieja conocida Relación mercurina de la admirable aparición de N.S. la Virgen María de Guadalupe en la lengua mexicana genuina y traducida al castellano. -Bib. Nac. de París, ms. 303. Colección Goupil; a continuación, en el paquete 20bis, se añade: Tezoro (sic) maestro genuino del elegantísimo idioma mexicano, ff. 81 a 89. -Martirio de los niños Cristobalito y otros, escrito por Motolinía, ff. 90 a 106. - Historia de la ciudad de México desde su fundación Ė, ff. 107 a 126. Como apéndice 3 al libro de Silvio Zavala (pp. 555-600, en especial pp. 580-582), y asimismo como publicación independiente en 1939, Jiménez Moreno cataloga con más detalle La "Colección Troncoso" de fotocopias de manuscritos. Los citados paquetes $20 \mathrm{y}$ 20bis con las obras de Pérez de la Fuente ocupan las pp. 26-28. Con Jiménez Moreno nos enteramos de que las fotografías y microfilms no tuvieron un aterrizaje muy pacífico que se diga, pues de los 126 folios que contiene el ms. 303, faltan copias de los ff. 31-39 y 52-80 (casi una tercera parte).

En todo caso, Pérez de la Fuente gozaba de una nueva oportunidad para ser leído, editado, traducido, degustado y estudiado en su México natal..., pero nada de eso ocurrió. Un manto de silencio volvió a cernerse sobre su obra mestiza, escrita mayormente en náhuatl, con presencia ocasional del español. Con una excepción apenas: en 1951, Rex Edward Ballinger defendió su tesis doctoral en la Facultad de Filosofía y Letras de la UNAM, con el título Los orígenes del teatro español y sus primeras manifestaciones en la Nueva España, que permanece inédita y fue de difícil acceso durante mucho tiempo, pero que hoy se encuentra fácilmente en el repositorio digital de la citada Universidad (TESIUNAM). A nosotros nos interesa el "Apéndice" de las pp. 131-142, donde se incluye la Loa satírica en una comedia en la fiesta del Corpus hecha en Tlayacapa 1682, la cual tomó del citado manuscrito de Faustino Galicia Chimalpopoca. Ballinger cuenta con la ayuda de Ignacio Dávila Garibi, quien a partir de la propia traducción de Faustino Galicia vierte al castellano la loa inserta en el apéndice (pp. 135-142) ${ }^{29}$.

${ }^{29}$ Con todo, la transcripción de la loa es un desastre total, pues altera el orden de los versos y deja el texto ininteligible. He aquí el orden en que 
Era la primera vez que una obra de Pérez de la Fuente merecía la atención de la crítica académica. Casualidades de la vida, ésta fue precisamente la loa que Vallejo Villa y Díaz Cíntora atribuyeron medio siglo después (2001) a sor Juana Inés de la Cruz como si fuera su loa infantil perdida (ver infra, apartado 7).

Antes de concluir el siglo xx aún localizamos varias aproximaciones más al manuscrito parisino. Brinckmann lo describe sólo en parte (maneja el microfilm de México) en su tesis doctoral de 1969 titulada Quellenkritische Untersuchungen zum mexicanischen Missionsschauspiel (1533-1732), pp. 197-199, acción que repite en un artículo posterior mucho más accesible: "Coloquios de la Virgen de Guadalupe” (1978, pp. 164-165). Por otra parte, en el bien documentado ensayo de Poole sobre el origen y fuentes de la Guadalupana (1995, pp. 172-174 y 190-191), se citan dos obras de Pérez de la Fuente (la Relación mercurina y la comedia de $E l$ portento mexicano) que este crítico manejó directamente en París, haciendo buen uso de sus conocimientos de náhuatl ${ }^{30}$.

Si volvemos al ámbito mexicano y redirigimos nuestra mirada a las copias de Paso y Troncoso custodiadas en la Biblioteca Nacional de Antropología e Historia, observamos que Sandoval Aguilar cita parte de las fotografías sacadas al ms. 303 de la BNF. En concreto, en su Catálogo de manuscritos e impresos en lenguas indígenas de México (1991, pp. 41-44), aparecen estos ítems: Xácara en el idioma mexicano del 13 de agosto de 1713 (ficha 59); Mercurio encomiástico (asigna la mera función de "recopilador" a Pérez de la Fuente y sostiene erróneamente que el manuscrito es del siglo XVII; ficha 59); El portento mexicano, comedia (ficha 60); Relación mercurina de la admirable aparición de Nuestra Señora la Virgen María de Guadalupe (la da por anónima del siglo XVII, pasando por alto el aviso final de que estaba firmada por Pérez de la Fuente; ficha 61); Tesoro dos veces rico (ficha 63); Martirio de los niños Cristobalito y otros en Tlaxcala, por defender la religión cristiana (ficha 64); Historia de la aparición de la Virgen de Guadalupe, en náhuatl, del bachiller Lazo de la Vega (ficha 65). Por último, Sepúlveda y Herrera, en su aproximación a los Manuscritos en lenguas indígenas en los acervos de la Biblioteca Nacional de Antropología

Ballinger edita los 158 versos de esta loa: 1-17 (p. 135), 39-59 (p. 136), 81-102 (p. 137), 124-144 (p. 138), 103-123 (p. 139), 60-80 (p. 140), 18-38 (p. 141) y $145-158$ (p. 142).

${ }^{30}$ Sin embargo, ya queda dicho que cuando una década después el mismo Poole publique El portento mexicano (2006), optará por considerar anónima esta última comedia. 
e Historia (1999, pp. 94-96), desglosa también el contenido inicial del ms. 303 de la BNF (contenido inicial porque sólo llega hasta el f. 51 y omite lo relativo a los ff. 52-126).

\section{El manuscrito "Mexicain 303" de la Biblioteca NaGional de Francia}

Excepción hecha de don Francisco del Paso y Troncoso, que tuvo acceso directo al ms. 303 de la BNF (aunque, hasta donde sé, nunca publicó nada al respecto), y más tarde de Stafford Poole, hay una constante que se repite en la crítica mexicanista del siglo xx: todos los autores citados se sirven de la colección de fotografías y microfilms que hizo don Francisco, de la cual faltan bastantes folios, como se ha dicho, casi una tercera parte del total (no constan los ff. 31-39 ni 52-80) ${ }^{31}$. Así que todas ellas son descripciones o catalogaciones parciales, con el inconveniente que acarrea el no haber realizado la consulta del manuscrito original de Pichardo. El principal problema es que en esta cadena de transmisión de datos se ha ido difuminando (o no se enfatiza lo suficiente) la responsabilidad autorial de Pérez de la Fuente en la mayor parte del manuscrito, hasta convertirlo en un simple mediador o copista, con lo cual se acaba deformando la realidad.

Para solventar esta laguna crítica es que nos hemos desplazado a la BNF en París, sede Richelieu, y hemos manejado directamente el manuscrito de la "Collection Goupil-Aubin", clasificado como "Mexicain 303". Se trata de una copia a mano que hizo el padre Pichardo a partir del original de Pérez de la Fuente, original perdido durante siglos y que acaba de aparecer en los registros bibliográficos de la Firestone Library, en la Princeton University (ver infra, apartado 6). Por muy esmerado que sea el amanuense, y Pichardo lo es, no existe la copia perfecta, así que no faltan pasajes con erratas, omisión de algún verso, etc. ${ }^{32}$ Compárense estos dos frag-

31 La Biblioteca Nacional de Antropología e Historia de México dispone de dos reproducciones parciales del manuscrito 303: una en papel fotográfico con revelado en negativo (fondo en negro) y otra en microfilm: Colección Francisco del Paso y Troncoso, legajos 65 y 66 , paquetes 20 y 20 bis.

32 Díaz Cíntora detecta un par de fallos en la Loa satírica donde se rompe la alternancia en los asonantes (2001, pp. 73 y 74). Tales fallos no proceden de Pichardo, que copia bien, sino del propio Pérez de la Fuente. 
mentos de la loa titulada Apláudese la fineza que el Señor hizo en quedar sacramentado con los hombres y se verá cómo Pichardo pierde dos versos:

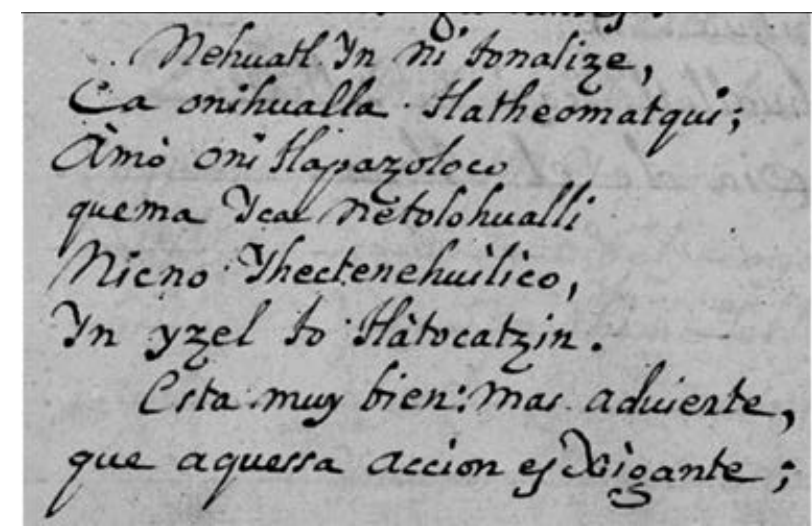

IMAGEN 10. Firestone Library, ms. C0744.02, f. 182bis (autógrafo de Pérez de la Fuente).

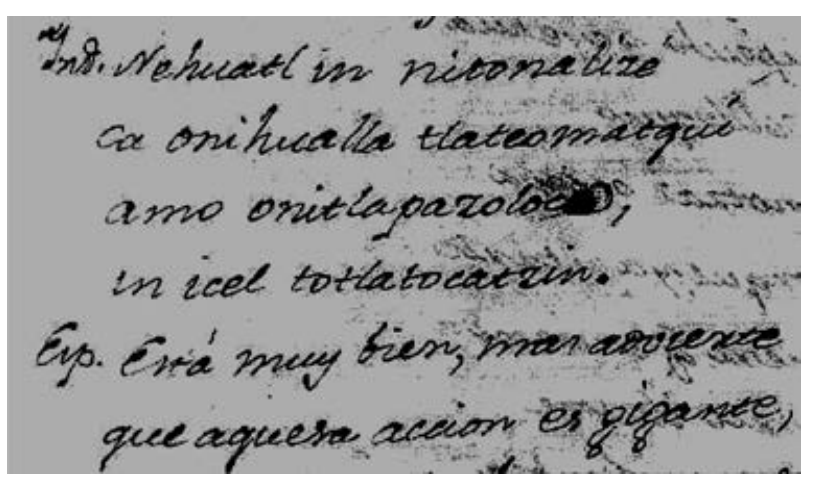

IMAGEN 11. BNF, ms. Mexicain 303, f. $50 \mathrm{v}$ (copia de Pichardo).

Aun con todo, este manuscrito parisino sigue siendo referencia de primer orden, por lo que procedo a detallar el contenido de sus 126 folios.

Ff. 1r-11r Relación mercurina de la admirable aparición de Nuestra Señora la Virgen María de Guadalupe, en la lengua mexicana genuina, y traducida en castellano.

Nota final, en el f. 11r: "Y por verdad lo firmo en Amecamecan, a 6 días del mes de mayo de 1712 años. Joseph Pérez de la Fuente". 
Texto a dos columnas, escrito en náhuatl a la izquierda y con la traducción castellana a la derecha.

Ff. 11r-30r El portento mexicano. Comedia famosa y la primera en verso mexicano.

Personas que hablan en ella: El señor Juan Diego; El señor obispo Zumárraga; Totopochtli, criado; María Lucía, su esposa; Juan Bernardino; Tres pajes del señor obispo; Un viejo, suegro de Juan Diego; Cacahuatzin, criada; Dos indios.

Texto en náhuatl (aunque se escriben en español las acotaciones escénicas) que ocupa la columna de la izquierda y conserva en blanco la columna opuesta para una previsible traducción, la cual nunca se materializó en el manuscrito ${ }^{33}$. Ff. 31r-39v Borradores ociosos y mercurinos traductos del idioma mexicano. Año de 1713. Ofrecimiento del Rosario, que compuso el R.P.M. Fray Francisco Sánchez, del Orden de Predicadores, impreso en México, por la viuda de Miguel de Rivera Calderón, año 1707. Traducido en mexicano por Joseph Pérez de la Fuente ${ }^{34}$.

${ }^{33}$ En la New York Public Library se conserva otra copia manuscrita de la comedia, dentro de un conjunto de papeles varios agrupados bajo el rótulo de Monumentos guadalupanos. En la Primera Serie, tomo $2^{\circ}$ de tales Monumentos guadalupanos, ff. 81-119, es donde se aloja esta nueva copia manuscrita en náhuatl de El portento mexicano, pero sin atribución de autoría. En el colofón (ff. 118v-119r) se declara esto: "Es copia sacada de un manuscrito que se conserva en la Biblioteca de Catedral, y traducida por el que suscribe, de orden del señor conservador del Museo Nacional, licenciado don J. F. Ramírez. México, 12 de noviembre de 1856. Licenciado Faustino Chimalpopoca Galicia [firma y rúbrica]". Además, a continuación de esta copia, va una traducción al castellano realizada por el propio Faustino Chimalpopoca Galicia, la cual podría datarse también hacia 1856, aunque carece de colofón. La traducción ocupa los ff. 120155 del mismo manuscrito. El dato concuerda con Poole (1995, p. 276, n. 63; 2006, p. 13). Entre los papeles de los citados Monumentos guadalupanos hay más textos de Pérez de la Fuente, como por ejemplo una "Canción a Nuestra Señora de Guadalupe en verso mexicano del Maestro Joseph Pérez de la Fuente, año de 1719", la cual ocupa las dos caras del folio 190 de la Primera Serie, tomo 1. Se trata de la "Canción" autógrafa que reproducimos en las Imágenes 1 y 2 de este artículo. Merced a la puntual información del Dr. Alejandro González Acosta (que mucho agradezco), cabe añadir que en una biblioteca privada de Ciudad de México se alberga otro manuscrito de El portento mexicano, el cual consta de 12 fojas, en cuarto, marquilla, con esta data: "San Mathías y Febrero 24 de 1713". El citado manuscrito se vendió en una subasta de la Galería Morton el sábado 28 de octubre de 2006, y procedía -al parecer- de la biblioteca de Salomón Halle, quien a su vez lo obtuvo de los herederos de José María de Ágreda y Sánchez, famoso coleccionista que en el siglo xıx había comprado, en tiempos de la desamortización, fondos originarios de iglesias y conventos, como el Nuevo -o Grande- de San Francisco (González Acosta en prensa).

34 Jiménez Moreno (1939, p. 26) advierte que faltan estos folios de entre 
Texto a dos columnas, en náhuatl a la izquierda y en español a la derecha.

F. 40r-40v Jácara en el idioma mexicano que cantó un moderno en una concurrencia de indios principales, en 13 de agosto de 1713 años.

Texto en náhuatl, sin traducción al español.

En los ff. 40v-49r van insertos los textos dramáticos del Mercurio encomiástico, que se estructuran así:

F. 40v Mercurio encomiástico en la excelentísima lengua mexicana o náhuatl, hechas en diversos tiempos desde el año de 1682, que en Tlayacapa me hizo hacer Don Juan Hipólito Cortez Quetzalquauhtli y Tequantepehua este Encomio al Santísimo Sacramento. 1.

Texto en náhuatl. El número 1 y sucesivos (la serie discurre hasta el 20) aparecen en el manuscrito con una tinta más clara. Se añadieron después del proceso de copia (quizás por mano diferente); incurren en un error de conteo y -sobre todo- no coinciden con la sucesión numérica del autógrafo de Princeton. Resalto en negrita esta numeración para facilitar su visibilidad, con el aviso de que en el documento parisino no se hace tal distingo. Véase la ubicación del núm. 1 en la imagen adjunta, entre el título y el primer verso.

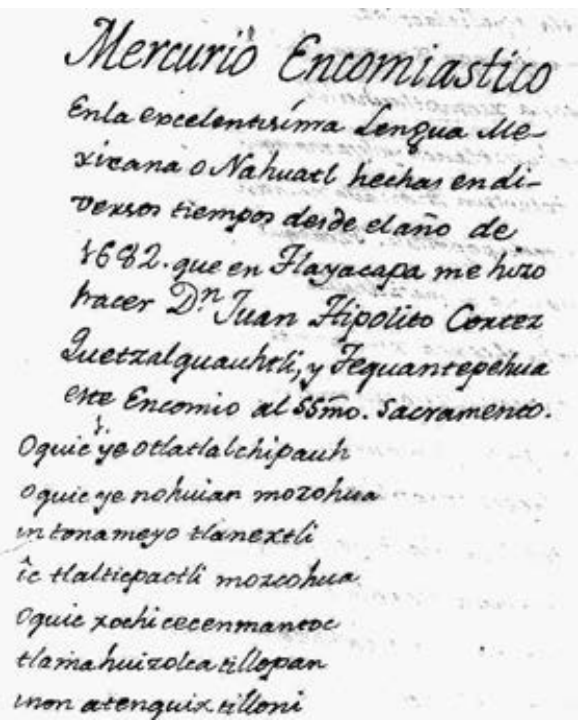

Imagen 12. BNF, ms. Mexicain 303, f. 40v. Letra de Pichardo.

las fotocopias de Paso y Troconso. Es por eso que Sepúlveda y Herrera (1999) tampoco los registra. 
Ff. 40v-41v El año de 1686, en Amecameca, recitó esta loa Don Sebastián Constantino, hoy gobernador y entonces niño, a la Santísima Virgen. 2.

F. 41r En otra ocasión se dijo desde donde está esta señal * de esta manera.

F. 41v Aqui arriba, desde donde esta señal * antes del paréntesis, se prosiguió de esta otra manera.

Estos tres textos, que conforman la loa número dos con sus variantes, están escritos en náhuatl.

F. 42r-42v El año de 1687 se recitó esta loa en Amecamecan, a la Asunción de Nuestra Señora. 3.

Texto en náhuatl.

Ff. 42v-43r Encomio festival a la Asunción de Nuestra Señora, en el pueblo de Ayapanco, año de 1691. 4.

Texto en náhuatl.

F. 43r-43v El año de 1692. Encomio en la noche de la fiesta del señor Santiago, que Ayapanco celebró cuando lo sacaron en un carro triunfal. [4bis]

Texto mixto ('mestizo, bilingüe') con unas partes en náhuatl y otras en castellano. Este Encomio queda sin numerar, lo cual provoca un error en la cuenta de los textos que integran el Mercurio encomiástico, de modo que en realidad se copian 19 loas o encomios, aunque la serie vaya del 1 al 18 . Para simplificar las cosas, identificaré este encomio como $4 \mathrm{bis}$.

Ff. 43v-44r Prosíguese el furor poético para honra y gloria de Dios, y en el modo mixto que se ve se recitó en Tlayacapan el año de 1698 este elogio a San Juan Bautista. Núm. 5.

Texto mixto entre náhuatl y español. El número cinco, como acabamos de señalar, supone un error en el conteo, pues le correspondería el número seis, y así sucesivamente hasta el final. No vuelvo a consignar este detalle.

F. 44r-44v El año de 1701 se aplicó la introducción de este elogio a Nuestra Señora de los Remedios, y comenzó desde... Núm. 6.

Texto mestizo.

Ff. 44v-45r Elogio festival al señor San Luis Obispo en Tlalmanalco, año de 1705. 7.

Texto en náhuatl.

F. 45r-45v El año de 1706 se hicieron los elogios en lengua mexicana a la dedicación del nuevo templo de Nuestra Señora de Guadalupe, y con ser merced del Señor nunca vista, no tuvo lugar, por mis pecados. Año de 1710 se hizo esta loa en Tlalmanalco, en fiesta que hizo el Reverendo Padre cura ministro Fray Antonio de 
la Madrid a la colocación de una imagen de la Asunción de Nuestra Señora, y empieza la loa de San Juan desde donde dice... Núm. 8.

Texto mestizo.

F. 45v El año de 1706 se hizo este encomio a la festividad del Corpus Christi. 9.

Texto en náhuatl.

F. 46r Año de 1707 en Nativitas de Tlaxcallan, se recitó este elogio a la Natividad de Nuestra Señora. 10.

Texto en náhuatl.

F. 46v El año de 1706 en un carro se recitó este encomio a Nuestra Señora del Socorro. 11.

Texto mestizo.

F. 47r El año de 1706 se hizo este encomio a la Natividad de Nuestra Señora. $12^{35}$.

Texto en náhuatl.

F. 47r El mismo año se hizo a Nuestra Señora del Socorro en Tlalmanalco. 13.

$\mathrm{Al}$ final se añade esta nota: "La introducción o exordio de este encomio es el del número 17, al Rosario".

Texto mestizo.

F. 47r El año de 1710 se hizo este elogio al Señor y a San Antonio del pueblo de Zoyatzinco. 14.

Texto mestizo, con predominio de voces en castellano sobre las propias en náhuatl.

F. 47v El año de 1708 se hizo esta canción a Nuestra Señora de Guadalupe, y se ha celebrado mucho. 15.

Texto en náhuatl.

F. 48r Versos al glorioso Patriarca Señor San Joseph, mi señor. Tlalmanalco, año de 1710. 16.

Texto en náhuatl.

F. 48r Encomio mixto a la festividad del Santísimo Rosario, año de 1713. 17. título.

Texto mixto o mestizo, como bien especifica el propio

Ff. 48v-49r Año de 1713 en Amecamecan. Jácara que hice para corregir a un hijo mio, año de 1713, en Amecamecan, a los 13 de agosto de dicho año. $\mathbf{1 8}^{36}$.

35 Sepúlveda y Herrera (1999) olvida mencionar este ítem.

36 Como bien advierte Poot Herrera (2009, pp. 209-210; 2009a, p. 371), se trata del mismo texto copiado más arriba, en ff. 40r-40v: Jácara en el idioma 
Texto en náhuatl (la palabra "Dios" aparece siempre en castellano).

$\mathrm{Al}$ final va esta protesta de fe del autor: "Todo lo contenido en este Mercurio encomiástico o furor poético, sujeto a la corrección de Nuestra Santa Madre la Iglesia Católica Romana. Y si en esto o en todo lo que hubiere escrito en este idioma se hallare algo disonante a sus sagrados dogmas, lo retracto corregido, tan obediente como ignorante. Y por verdad lo firmé en el pueblo de Amecamecan, a los 27 días del mes de octubre de 1713 años. Joseph Antonio Pérez de la Fuente y Quijada” (f. 49r).

Ff. 49r-50r Loa satírica en una comedia en la festividad del Corpus hecha, y recitada en Tlayacapan, año de 1682. 19.

Texto mixto, mayormente en náhuatl, pero con palabras o incluso versos enteros escritos en castellano. Véanse los vv. 2, 3 y 4 de la imagen adjunta.

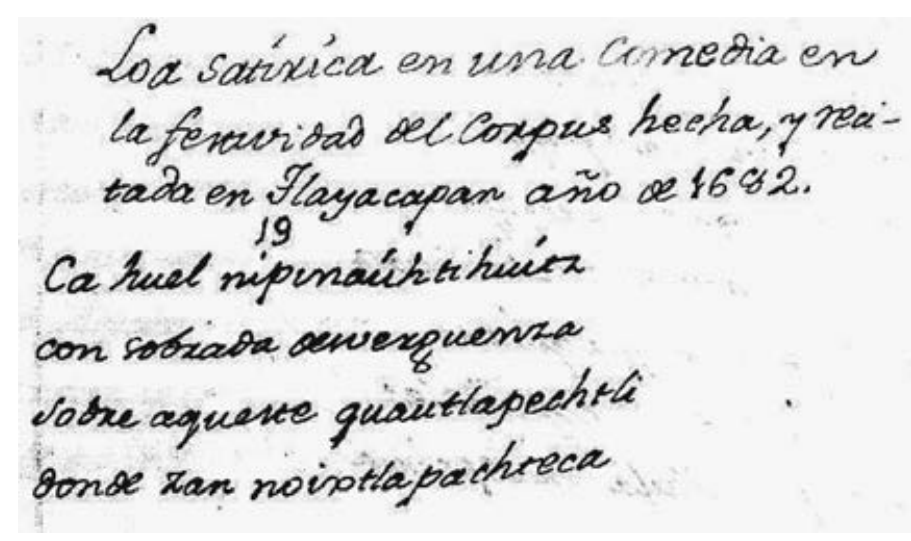

IMAGEN 13. BNF, ms. Mexicain 303, f. 49r. Letra de Pichardo.

Ff. 50r-51v Apláudese la fineza que el Señor hizo en quedar sacramentado con los hombres. Año de 1718. $\mathbf{2 0}^{37}$.

mexicano que cantó un moderno en una concurrencia de indios principales, en 13 de agosto de 1713 años.

37 En este punto concluye la descripción del manuscrito que hace SEPúLvEDA Y HERRERA (1999). 


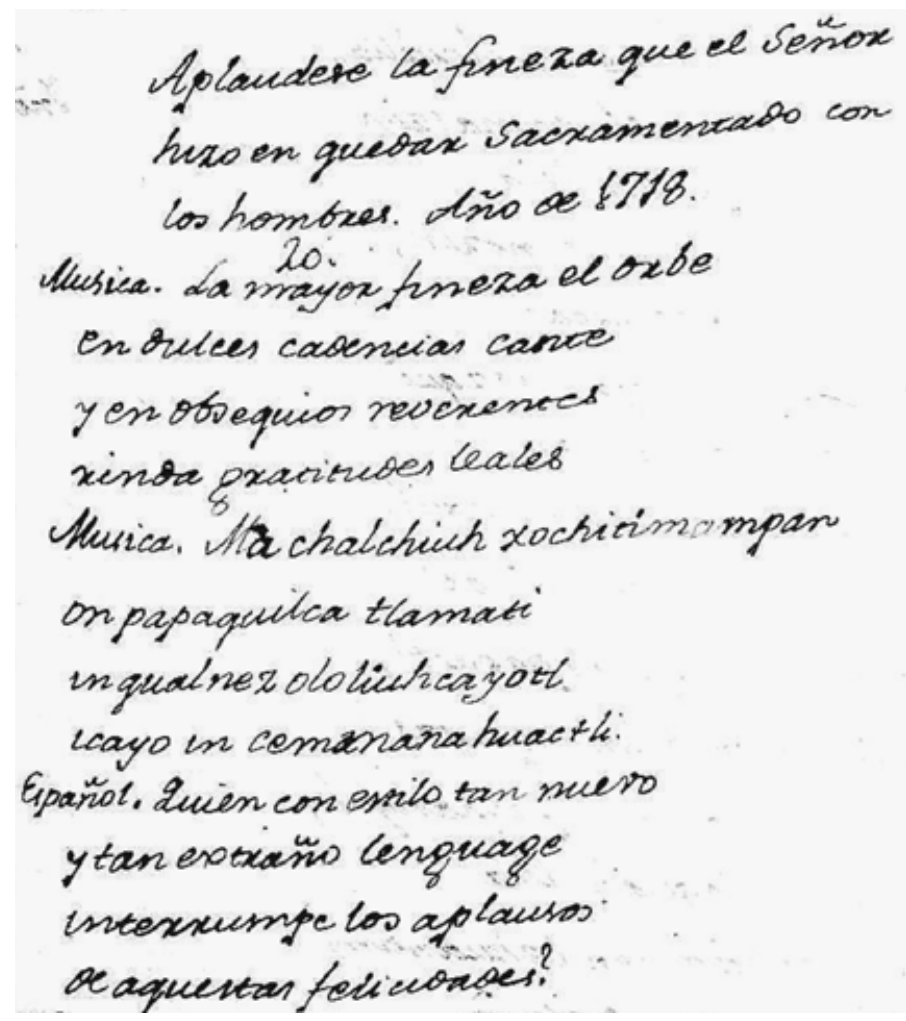

Imagen 14. BNF, ms. Mexicain 303, f. 50r. Letra de Pichardo.

Pieza mixta o mestiza en la que hablan un español y un indio, cada cual en su lengua materna. El tono cantado del inicio (dos cuartetas) también alterna el castellano con el náhuatl.

Los textos 19 y 20 -que distan entre sí la friolera de 36 años- son los que Díaz Cíntora y Vallejo Villa atribuyeron a sor Juana en Letras Libres (2001), aunque fusionados como si se tratase de una sola loa. Loera Chávez y Peniche, por su parte, no dudó en reeditarlos a nombre de sor Juana (2011, pp. 125-129 y 174-179), y lo vuelve a hacer en las pp. 193-206, ahora con traducción al español de María Elena Maruri Carrillo. El texto 19, sin embargo, ya había sido vertido al castellano en el manuscrito de Faustino Galicia (s. XIx) y en la tesis doctoral de Ballinger (1951, pp. 135-142).

Ff. 52r-64r Festivo día del alma, sacado de varios autores y traducido al idioma mexicano genuino según el Mercurio. Oración 
para antes del examen de la conciencia, sacada del libro del Destierro de ignorancias y aviso de penitentes ${ }^{38}$, a f. 89.

Le siguen varias oraciones más tomadas de diferentes autores. Texto a dos columnas, en náhuatl a la izquierda y español a la derecha ${ }^{39}$.

Ff. 64r-75v Sacra Philomena que discanta en el idioma mexicano los misterios del Santísimo Rosario.

Texto en náhuatl en su mayor parte, con fragmentos en español que van en la columna de la derecha, según lo acostumbrado.

Ff. 75v-79r Práctica breve para ayudar a bien morir, recopilada del ritual romano y de varios autores, que consagra al glorioso arcángel San Miguel el Doctor Don Alonso Alberto de Velasco. Traducido al idioma mexicano genuino.

Ff. 79r-80v Interrogatorio utilísimo para confesar indios mexicanos.

Texto mestizo, distribuido a dos columnas, en náhuatl a la izquierda y español a la derecha.

Ff. 81r-82r Ave María. Tezoro dos veces rico, aunque sin valor alguno. Maestro genuino del elegantísimo idioma náhuatl.

Fábrica continuada desde los 26 de setiembre del año de 1666, hasta 20 de julio de 1704, que para honra y gloria de la soberana majestad de Dios Nuestro Señor y de la Sacratísima Emperatriz de los cielos y de la tierra, mi Señora, se acabó en el pueblo de San Luis de Tlalmanalco.

Texto en español.

$\mathrm{Al}$ final del f. 82r se añade lo siguiente: "Nota: comencé a sacar el Mercurio en 8 días del mes de septiembre de este presente año de 1705 , y lo acabé hoy martes 10 de noviembre de dicho año. Sea para mayor honra y gloria de la majestad divina de Dios y de mi ama y mi señora, la Virgen María, que es quien me enseñó y guio; porque yo, ¿qué podía hacer, la misma miseria y flaqueza que soy?"

Ff. 82v-89v Ejemplos de la única y general declinación de nombres en el idioma náhuatl.

38 Se trata del libro del P. Alonso de Vascones (OFM), Destierro de ignorancias y aviso de penitentes, muy reeditado en España: 1614, 1615, 1620, 1622, $1623,1626,1632,1644,1662,1663,1667,1670,1674,1676,1685,1718,1720$, 1732, 1733, 1737, 1760, 1770, 1777, 1788, etc. También se imprimió en México, por Joseph Bernardo de Hogal, en 1728.

39 Jiménez Moreno (1939, p. 26) indica que en la Colección Troncoso no constan las fotocopias de los ff. 52-80. 
Texto de carácter lexicográfico y gramatical. Se trata de una continuación o complemento al Tesoro dos veces rico que le precede.

Ff. 90r-99r Esta historia que aquí se refiere es la misma que escribió en lengua castellana el padre fray Toribio Motolinía, uno de los doce primeros religiosos de Nuestro Padre San Francisco que vinieron a esta Nueva España; y se tradujo en la mexicana por el Padre fray Juan Bautista Guardián, del Colegio de Santiago Tlatilulco de México.

Capítulo primero en que se refiere cómo el niño Cristóbal recibió la fee de Jesucristo y le evitó a su padre la adoración de los ídolos, exhortándolo para que mudara de vida y se quitara de la embriaguez, con cuyo vicio podría tener una muerte desastrada.

Texto a dos columnas: en náhuatl a la izquierda y en español a la derecha. Son once capítulos, pero el último (f. 99r) aparece tachado, con una línea que cruza el folio de arriba a abajo.

Ff. 99v-106v México, año de 1791. Traducción de las vidas y martirios que tuvieron tres niños principales de la ciudad de Tlaxcala, la cual practicó el intérprete general de esta Real Audiencia, en virtud de lo mandado por el excelentísimo señor Conde de Revillagigedo, virrey gobernador y capitán general de este reino.

Texto a dos columnas: en náhuatl a la izquierda y en español a la derecha ${ }^{40}$.

Ff. 107r-126v Copia de lo más substancial de un cuaderno en mexicano, que le falta la primera hoja y algunos pedazos de otras. Y contiene la Historia de México desde su fundación, de autor anónimo.

Texto en dos columnas, ambas en náhuatl. La Historia comprende desde 1398 hasta 1524. Sigue una relación en náhuatl de los milagros que hizo la Virgen de Guadalupe (Nicam Motecpana in ixquich tlamahuizolli...), firmada al final por el Doctor Luis Lazo de la Vega.

Es claro que los tres últimos bloques, desde el f. 90r hasta el f. 126v, no pertenecen a Pérez de la Fuente: la traducción de Motolinía al náhuatl ya se señala que la hizo fray Juan Bautista

40 Sandoval Aguilar (1991, p. 44) apostilla lo siguiente: "Publicado en: Motolinía, Toribio, Memoriales de fray Toribio Motolinía. Manuscrito de la colección del señor don Joaquín García Icazbalceta: publícalo por primera vez su hijo Luis García Pimentel, México. En casa del editor, 1903”. 
Guardián; la tardía fecha del siguiente ítem (1791) imposibilita que él sea su autor; la larga relación final con los milagros de la Guadalupana va firmada por Luis Lazo de la Vega ${ }^{41}$. Pero el resto de ítems aquí descritos, desde el f. 1r hasta el 89v, son claramente textos escritos y/o traducidos por José Antonio Pérez de la Fuente.

\section{Hallazgo del manuscrito autógrafo de Pérez de la Fuente}

La prestigiosa Firestone Library de Princeton University, dentro de la Robert Garrett Collection (referencia C0744.02, Garrett Mesoamerican Manuscripts, núm. 10), custodia un volumen manuscrito cuyas medidas son de 31 x $22 \mathrm{cms}$. y contiene 75 folios (cubierta $+72 \mathrm{ff}$. de texto + portadilla de Borradores ociosos + hoja de guarda $)^{42}$. El norteamericano Robert S. Garrett (18751961) fue un atleta olímpico que ganó varias medallas en los juegos de Atenas (1896) y París (1900). Más tarde se hizo banquero, coleccionista de arte y bibliófilo. En 1942 depositó en la Universidad de Princeton más de 10000 manuscritos y en 1949 acabó donándolos. Entre ellos, figura el que nos atañe de Pérez de la Fuente, con una dedicatoria en el folio de guarda (1r) que dice así: "Don Nicolás León / Querido amigo / Este manuscrito lo obtuve de la / biblioteca de Don Francisco de Paso y Troncoso / desean[do] le sea de alguna utilidad / se le obsequia con cariño / Luis Bello”. Deducimos de aquí que José Luis Bello y Zetina (1889-1968) adquirió este manuscrito, "entre otros muchos papeles, de las señoritas Del Paso y Troncoso, parientas de don Francisco, en cuyo poder había dejado parte de su biblioteca al partir para Europa" (Palomera 1988, p. 163). Esto debió ocurrir después de 1916, año de la muerte de don Francisco. El siguiente eslabón de la cadena nos conduce hacia Nicolás León Calderón (1859-1929), quien en un momento dado (él o sus herederos) lo volvería a vender; quizás a William Gates, quien en 1930 los revendería a Robert S. Garrett (Sachse 2009, p. 5), o quizás directamente a este último. Lo paradójico del proceso es ver cómo Francisco del Paso y Troncoso se desplazó a Europa para

41 Más detalles en Jiménez Moreno 1939, pp. 27-28.

42 Agradezco a Princeton University y a mi colega Beatriz Carolina Peña las facilidades prestadas, a nivel institucional y personal, para el manejo de este manuscrito. 
recopilar documentos sobre México, fotografiando en París la copia que Pichardo hizo a las obras de Pérez de la Fuente, cuando resulta que él tenía en su casa mexicana el manuscrito autógrafo original. Como murió en Europa sin regresar a su patria, al final este raro manuscrito salió de México y acabó alojado en Princeton. Confiemos en que a partir de ahora, con su recuperación para la comunidad científica, se reivindique la figura de su autor, el mestizo Joseph Antonio Pérez de la Fuente y Quijada.

\subsection{Descripción del manuscrito}

El manuscrito carece de tapa dura y sus hojas están simplemente cosidas a mano, con un trozo de papel en el lomo. El folio que hace las veces de cubierta es de un papel diferente al resto, reutilizado, que presenta una cara con pruebas de pluma (probationes pennae) y otra cara -el reverso- con texto escrito ajeno al tema. En la cubierta se lee claramente " $\mathrm{N}^{\circ} 32$ Invent $^{\circ} 8$ ", que remite con toda certeza al ítem 32 del octavo y último inventario que se hizo del Museo Boturini, el día 28 de septiembre de 1743 (ver supra, apartado 3).



IMAGEN 15. Firestone Library, ms. C0744.02, cubierta.

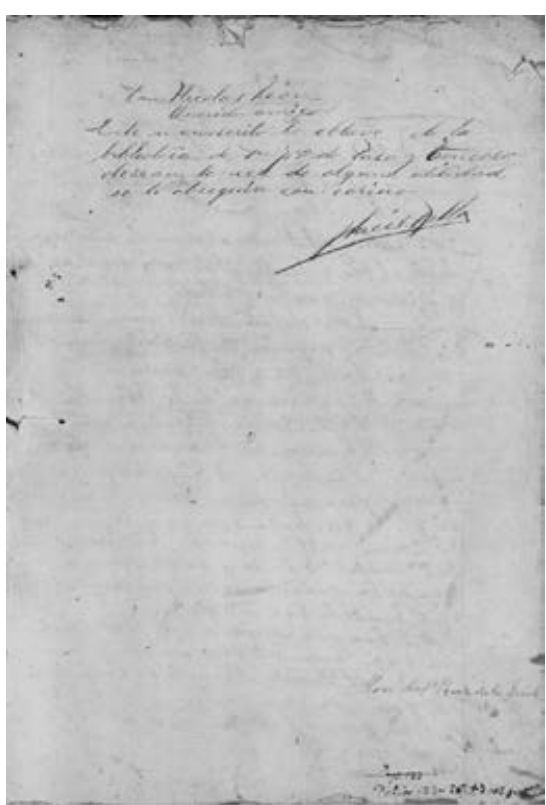

IMAGEN 16. Firestone Library, ms. C0744.02, hoja de guarda (1r). 
Tras esta humilde cubierta llegan dos hojas de guarda, sin paginar, con la tabla de contenidos, las cuales dan paso de inmediato a los folios de texto con numeración corrida desde el 123 hasta el 207 (es de notar que en distintos momentos se añadieron varias fojas más sin numerar). En algunas páginas del interior se observa el efecto de las termitas, que han devorado partes de papel y de texto, aunque por fortuna los daños son mínimos.

Contiene varias obras de diferentes fechas y géneros, con las cuales ya estamos familiarizados desde el "Catálogo" de Boturini. La Firestone Library data el documento entre 17091718 y asigna a todo el conjunto el título del primer ítem, que reza así: Tradúcese al romance castellano la relación mercurina de la aparición de Nuestra Señora la Virgen María, que está en la lengua mexicana genuina (es el folio inicial, aunque la numeración empieza por el 123r). Se trata de un manuscrito del puño y letra de Joseph Antonio Pérez de la Fuente (autógrafo todo él excepto un folio, el 193bis, que es de otra mano y copia la Loa satíri$c a$ ), quien además estampa su firma varias veces: ff. 132v, 149r, 192v, 193v, 207r y 207v. Las múltiples fechas consignadas en los documentos, en un arco que va desde 1682 hasta 1718, señalan que Pérez de la Fuente trabajaba con distintos borradores y que en un momento dado los reunió y pasó a limpio, fabricando así un hológrafo. Hasta en tres ocasiones deja constancia del manejo de tales borradores (ff. 164v, 182r y 199r) ${ }^{43}$. La tarea de copia la ejecutó de modo preferente entre 1712-1714, años en que pasó a limpio y puso en orden sus propios originales, los cuales venía elaborando desde 1666 (ver infra, notas a los ff. 132v, 149r, 207r y 207v).

La "Tabla" o índice nos previene de que buena parte del contenido inicial del manuscrito ha desaparecido: faltan los ff. 1-89 con la traducción del Arte de Nebrija; faltan los ff. 90-122 con la traducción de la Doctrina de Ripalda (el catecismo); faltan los ff. 135-145 que contenían un encomio sacramental, una adoración a la Trinidad y dos loas a la Virgen de Guadalupe; y faltan también los ff. 150-160 con la comedia El portento mexicano. Puede afirmarse que el original se desgajó en tiempos de

43 Desconozco si ha sobrevivido alguno de estos borradores, lo cual no sería extraño, habida cuenta de lo comentado a propósito de la Canción a Nuestra Señora de Guadalupe en verso mexicano, pues disponemos de dos copias autógrafas de la misma, una en la New York Public Library y otra en la Firestone Library (Princeton). 
Boturini y no después: el 28 de septiembre de 1743, día del octavo inventario, se declara que el manuscrito tenía 79 folios, o sea, casi los mismos que ahora (Peñafiel 1890, t. 3, p. 66; López, 1925 , p. 50). No sería raro que, tarde o temprano, acaben apareciendo las partes faltantes por algún lado. Paso a transcribir completa, por la relevancia que tiene, la tabla de contenidos:

\section{Amecame y octubre 28 de 1714}

Tabla que contiene las obras sacadas por el Mercurio y Arte de el idioma mexicano

-El Arte del Maestro Antonio de Nebreja, desde el f. 1 hasta el de 89, en planas de a cuarto. No se ha acabado.

- La Doctrina del Padre Maestro Jerónimo de Ripalda, de la Compañía de JESÚS, desde el f. 90 hasta 122. En cuarto.

- La Relación mercurina de la admirable aparición de Nuestra Señora de Guadalupe, en las dos lenguas, romance y mexicano. Desde f. ciento y 23 hasta 132. En pliego.

-Interrogatorio para confesar indios mexicanos, en el f. 133 hasta 134. En pliego.

-Un Encomio al Santísimo Sacramento, la Adoración a la Santísima Trinidad y dos Loas a Nuestra Señora de Guadalupe en la dedicación de su nuevo templo, desde f. 135 hasta el de 145. En cuarto.

- Práctica breve para ayudar a bien morir. Desde el f. 146 hasta f. 149. En pliego.

-Comedia El portento mexicano, en verso. Desde f. 150 hasta 160. En pliego.

—El día festivo del alma. Desde f. 161 hasta f. 182.

-El Mercurio encomiástico. Veinte loas en verso mexicano a diversos propósitos. Desde el f. 183 hasta el de 193. En pliego ${ }^{44}$.

-Desde el f. 194 hasta el de 207 se contiene el texto de $L a$ doctrina cristiana. Con muchas oraciones, todas con sus romances, cuyo título es Borradores ociosos y mercurinos traductos.

-Los tratados especiales son: El Mercurio cortesano, como el de D. Gabriel de Bocángel, f. 135. [Escrito posterior a lápiz: "falta"]. —Versos a Nuestra Señora de Guadalupe, f. 191.

44 Alguien ha añadido a lápiz -seguramente un bibliotecario de la Firestone Library- el aviso de que "falta foja 188". Como explicamos más abajo, se trata de un simple error de numeración, pero en realidad no se ha perdido ningún folio y el texto avanza sin interrupciones. 
-Versos al Señor San Joseph, f. 192.

- Una jácara para corregir a un moso, f. 193.

- Sacra Filomena que discanta los misterios del Santísimo Rosario en verso, f. 172.

—Consideración de la Santísima Trinidad, desde f. 180 hasta 182.

- El oficio de la Santísima Trinidad, f. 182.

—El oficio del Señor Sanc Joseph, f. 183. Luego se sigue el indio, etc.

—La Cartilla con todas las oraciones, desde f. 200 hasta 207.

Procedo ahora a describir en detalle el contenido del manuscrito:

F. 1r: original en blanco, de guarda, con posterior anotación del siglo xx que dice así: "Don Nicolás León / Querido amigo / Este manuscrito lo obtuve de la / biblioteca de Don $\mathrm{F}^{c o}$ de Paso y Troncoso / desean[do] le sea de alguna utilidad / se le obsequia con cariño / Luis Bello".

Ff. 1v-2r: Tabla de contenidos (f. 2v en blanco), ya transcrita.

Ff. 123r-132v: Tradúcese al romance castellano la relación mercurina de la aparición de Nuestra Señora la Virgen María, que está en la lengua mexicana genuina. En español, ff. 123r-126v. Luego llega la Relación mercurina de la admirable aparición de Nuestra Señora la Virgen María de Guadalupe, en la lengua mexicana genuina. En náhuatl, ff. 127r-132v. En la parte inferior del f. 132v se lee: "S.C.S.M.E.C.R. Y por verdad lo firmo en Amecamecan, a 6 días del mes de mayo de 1712 años. Joseph Pérez de la Fuente [firma y rúbrica]"

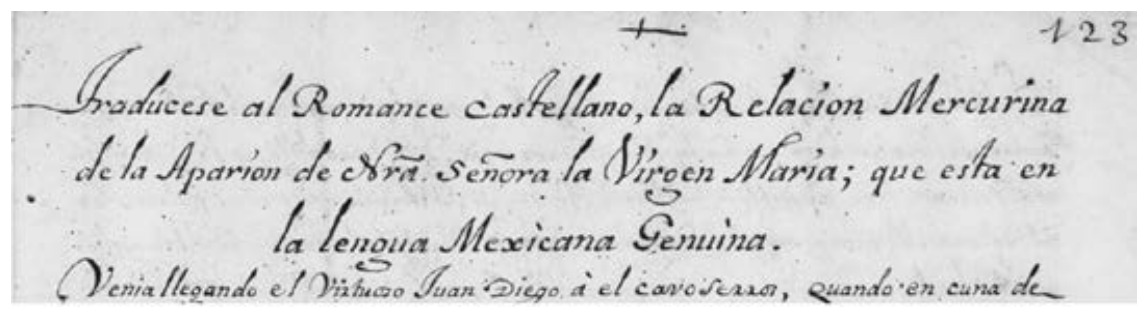

IMAGEN 17. Firestone Library, ms. C0744.02, f. 123 r.

${ }^{45}$ Las siglas "S.C.S.M.E.C.R.” significan Sub Correctione Sanctae Matris Ecclesiae Catholicae Romanae. 


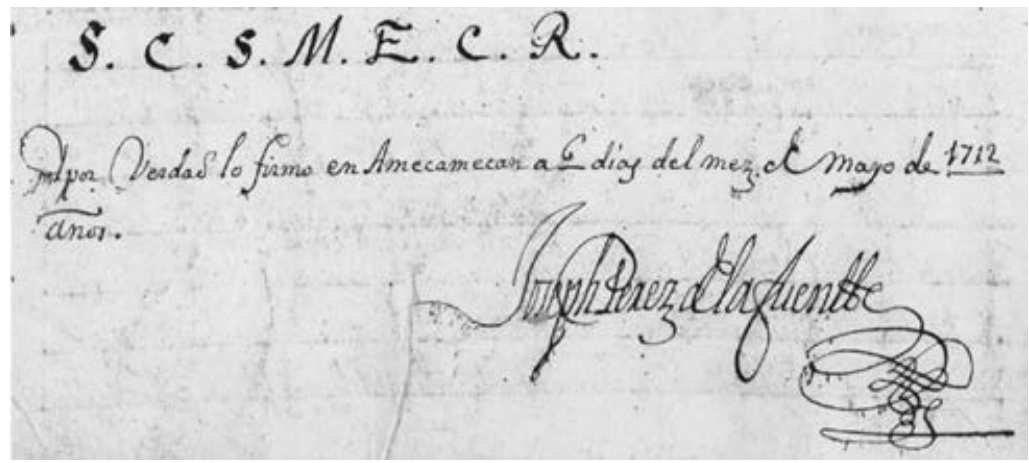

Imagen 18. Firestone Library, ms. C0744.02, f. $132 v$.

Ff. 133r-134v: Interrogatorio utilísimo para confesar indios mexicanos. Texto a dos columnas, a la izquierda en castellano y a la derecha en náhuatl.

Faltan los ff. 135-145, que según la "Tabla" inicial del manuscrito contenían "un encomio al Santísimo Sacramento. La adoración a la Santísima Trinidad. Y dos loas a Nuestra Señora de Guadalupe en la dedicación de su nuevo templo", en tamaño cuarto.

Ff. 146r-149r: Práctica breve para ayudar a bien morir, recopilada del Ritual Romano y de varios autores, que consagra al glorioso Arcángel San Miguel el Dr. D. Alonso Alberto de Velasco. Traducido al idioma Mexicano genuino. Texto íntegro en náhuatl. Al final del f. 149r se lee: "S.C.S.M.E.C.R. Y por verdad lo firmo en el pueblo de Amecame, en diez y ocho de junio de 1714 años. Joseph Pérez de la Fuente [firma y rúbrica]". El f. 149v queda en blanco.
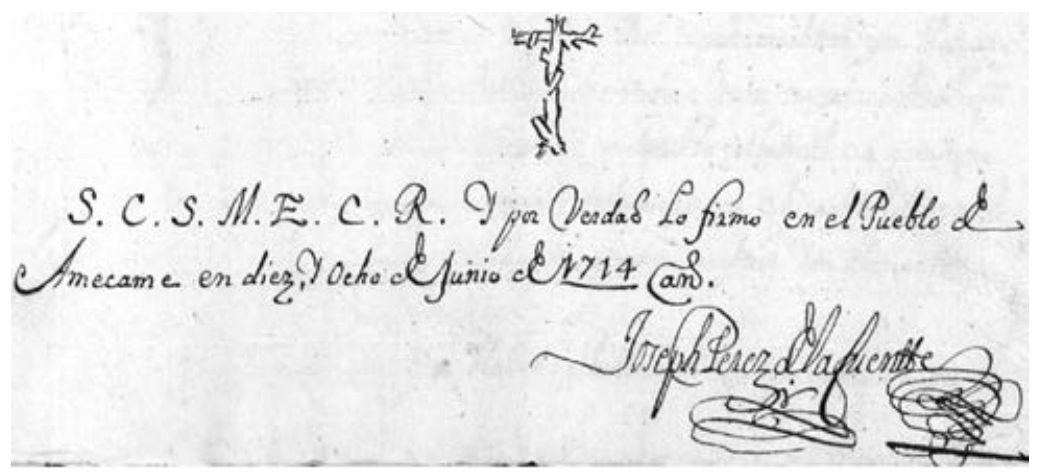

IMAGEN 19. Firestone Library, ms. C0744.02, f. 149 r. 
Faltan los ff. 150-160, que al decir de la "Tabla" corresponderían a la comedia El portento mexicano, en verso, en tamaño pliego.

Ff. 161r-182 (bis): Festivo día de el alma. Sacado de varios autores y traducido al idioma mexicano genuino, según el Mercurio. Julio 25 de 1714.

Contiene diversas oraciones, todas ellas en náhuatl:

- F. 161r-161v: Oración para antes del examen de conciencia, sacado del libro de el Destierro de ignorancias y aviso de penitentes, a f. ochenta y nueve.

- Ff. 161v-163v: Oración para antes de la confesión. Sacada del mismo libro, f. ciento y veinte y nueve. Datada en agosto 1 de 1714 años.

- F. 163v: Oración para después de la confesión. Es sacada del libro intitulado Tesoro espiritual del alma, f. 19.

- Ff. 163v-164r: Oración a Nuestra Señora para antes de la Sagrada Comunión. La saqué de un libro que no me acuerdo.

- F. 164r-164v: Oración para antes de comulgar. Sacada del libro intitulado Tesoro espiritual del alma, a f. 22. En la parte inferior del f. 164v pone: "Éste es el primer borrador, y es causa de las erratas".

- Ff. 165r-169r: Método para comulgar con mucho fructo, etc. Sacado del que compuso el P. Ignacio Javier de la Compañía de Jesús. Impreso en México por Francisco de Ribera Calderón, año de 1709.

- Ff. 169r-172v: Ofrecimiento del Rosario, que compuso el R.P.M. Francisco Sánchez, del Orden de Predicadores. Impreso en México por la viuda de Miguel de Ribera Calderón, año de 1707.

- Ff. 172v-178v: Sacra Philomena que discanta en el idioma mexicano los misterios del Santísimo Rosario.

- Ff. 178v-179v: Ofrecimiento de la hora a Nuestra Señora, que compuso el M.R.P. fray Francisco Sánchez, de la Orden de Predicadores, traducido por el Mercurio o Arte Mexicano.

- Ff. 179v-182r: Este parágrafo es de la primera Consideración de los Misterios Gozosos, del libro intitulado El arco iris, de el V.P. fray Pedro de Santa María y Ulloa. Sacada en Mexicano por Arte Mercurino. Al final consta la fecha del 22 de octubre de 1714 .

A continuación, en el mismo f. 182r se hace este aviso, con fecha de 17 de noviembre de 1714: "Por estar sacadas en borradores limpios no se ponen aquí las oraciones siguientes", y se citan cuatro de ellas. 
- F. 182r-182v: Por último se pone ahora el Oficio de la Santísima Trinidad, sacado del cap. Séptimo de el Apocalipsis, y es como se sigue.

- Ff. 182v-182 (bis): Esta oración es de un libro que se intitula Oración de cada día, y luego prosiguen los días de la semana.

Tras el f. 182, se interpolan en el manuscrito tres folios más sin numerar, que he dado en llamar 182bis, 182ter y 182quater.

La cara recta del f. 182bis concluye la Oración de cada día y añade esta frase: "Aquí se acaba el Festivo Día de el Alma".

La cara vuelta del f. 182bis y todo el f. 182ter contienen el siguiente texto: Apláudese la fineza que el Señor hizo en quedar sacramentado con los hombres. Año de 1718.

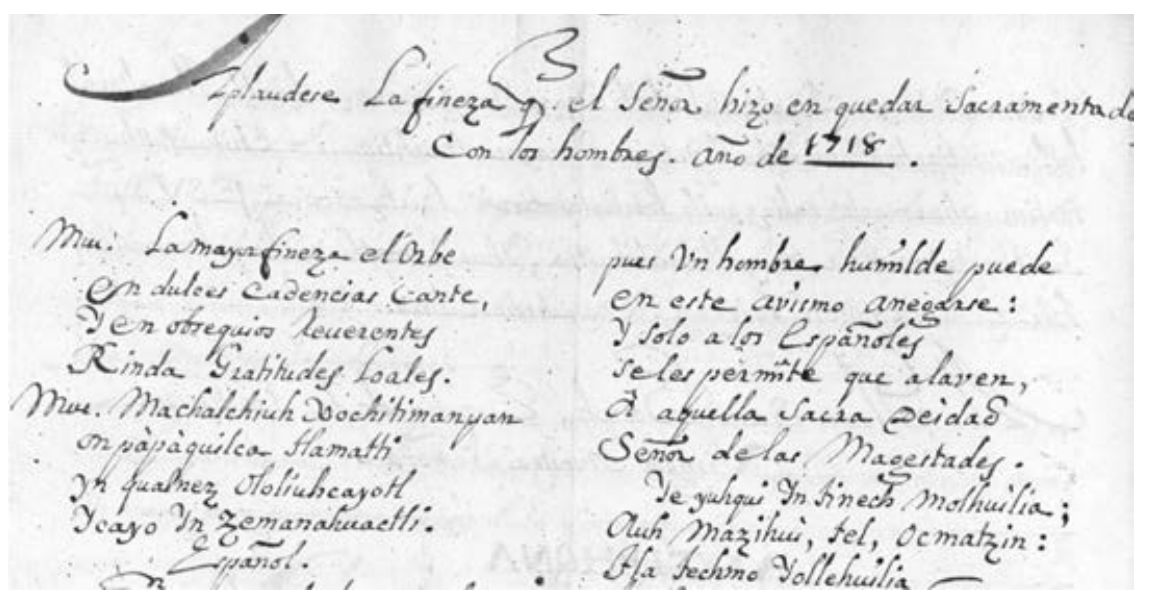

IMAGEN 20. Firestone Library, ms. C0744.02, reverso del f. 182bis.

La cara recta del que llamo f. 182quater copia una Jácara en el idioma mexicano que cantó un moderno en una concurrencia de indios principales, en trece de agosto de 1713 años.

La cara vuelta del f. 182quater empieza un tratado, sin nombre concreto, que queda inconcluso.

A partir de aquí, el manuscrito retoma la numeración correlativa de los folios.

Ff. 183r-193v: Mercurio encomiástico en la excelentísima lengua náhuatl. 


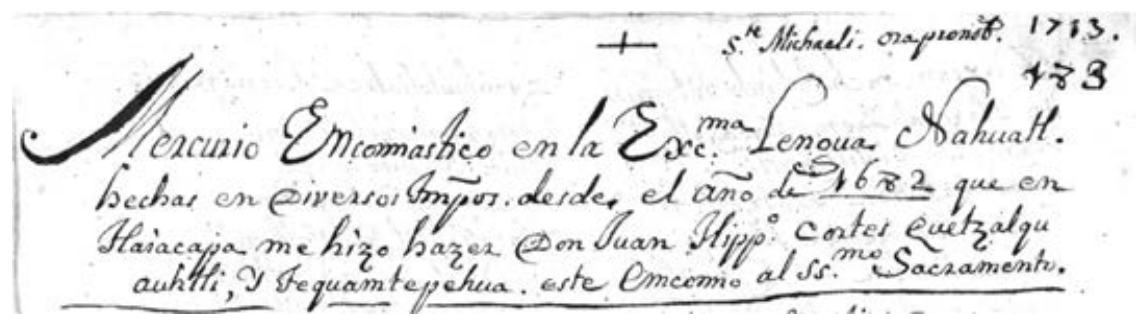

IMAGEN 21. Firestone Library, ms. C0744.02, f. 183 r.

El manuscrito escribe esto exactamente: "Mercurio encomiástico en la excelentísima lengua náhuatl. Hechas en diversos tiempos, desde el año de 1682 que en Tlayacapa me hizo hacer Don Juan Hipólito Cortés Quetzalquauhtli y Tequamtepehua este emcomio al Santísimo Sacramento" ${ }^{46}$. Pero el título -aunque nadie lo haya señalado todavía- es anacolútico, y no sabemos cuál es el sujeto del verbo "hechas". Creo que Pérez de la Fuente omitió involuntariamente algunas palabras del título, seguramente una línea entera (error que, por supuesto, pasó a la copia de Pichardo). Si vamos a la "Tabla" inicial de contenidos vemos que allí se decía esto: " $E l$ Mercurio encomiástico. Veinte loas en verso mexicano a diversos propósitos".



IMAGEN 22. Firestone Library, ms. C0744.02, Tabla del f. $2 r$.

A mi entender, el título correcto de esta sección del manuscrito sería: Mercurio encomiástico en la excelentísima lengua náhuatl. Veinte loas en verso mexicano a diversos propósitos, hechas en diversos tiempos. Las menciones al año 1682 y a don Juan Hipólito Cortés no afectan al conjunto de las veinte loas, como interpreta la crítica (Vallejo Villa, Díaz Cíntora, Loera...), sino tan sólo al primer ítem, el Encomio al Santísimo Sacramento. Aclarado esto, paso a detallar el contenido del original:

${ }^{46} \mathrm{El}$ aviso del ángulo superior derecho, "Sancte Michaeli, ora pro nobis. 1713", sugiere que Pérez de la Fuente estaba trasladando el manuscrito el día de S. Miguel (29 de septiembre) del año 1713. Indicar la fecha del traslado mencionando el santo del día es costumbre habitual de Pérez de la Fuente que se repite muchas veces en sus autógrafos. 
-F. 183r: Desde el año de 1682 que en Tlayacapa me hizo hacer Don Juan Hipólito Cortés Quetzalquauhtli y Tequamtepehua este Encomio al Santísimo Sacramento. $\mathbf{N}^{\mathbf{0}} \mathbf{1}$. [Repito la práctica utilizada en el manuscrito parisino de enfatizar en negrita los números arábigos de cada ítem].

-F. 183r-183v: El año de 1686, en Amecameca, recitó esta loa D. Sebastián Constantino, hoy gobernador y entonces niño, a la Santísima Virgen. $\mathbf{N}^{\mathbf{0}} \mathbf{2}$.

-Ff. 183v-184r: En otra ocasión se dijo desde donde está esta señal * desta manera. $\mathbf{N}^{\mathbf{0}} 3$.

-F. 184r-184v: En el $N^{\circ} 3$, desde donde dice que es paréntesis, se prosiguió con otra. $\mathbf{N}^{\mathbf{0}} \mathbf{4}$.

-Ff. 184v-185r: El año de 1687 se recitó esta loa en Amecame, a la Asumpción de Nuestra Señora. $\mathbf{N}^{\mathbf{0}} \mathbf{5}$.

-F. 185r-185v: Encomio festival a la Asumpción de Nuestra Señora, en el pueblo de Ayapanco, año de 1691. N 6.

-Ff. 185v-186r: El año de 1692, encomio en la noche de la fiesta del Señor Santiago, que Ayapanco celebró cuando sacaron en un carro triunfal. $\mathbf{N}^{\mathbf{0}} \mathbf{7}$.

-F. 186r-186v: Prosíguese el furor poético para honra y gloria de Dios, y en el modo mixto que se vee, se recitó en Tlayacapa el año de 98 este elogio al Señor San Juan Baptista. $\mathbf{N}^{\mathbf{0}} \mathbf{8}$.

-Ff. 186v-187r: El año de 1 se aplicó la introducción de este elogio a Nuestra Señora de los Remedios en México, y comenzó desde... N $\mathbf{N}^{\mathbf{9}}$.

-F. 187r-187v: Elogio festival al señor San Luis Obispo, en Tlalmanalco, año de 1705. $\mathbf{N}^{\mathbf{0}} \mathbf{1 0}$.

-Ff. 187v-189r: El año de 1706 se hicieron los elogios en lengua lengua [sic] mexicana a la dedicación del nuevo templo de Nuestra Señora de Guadalupe, y con ser Majestad del Señor nunca vista, no tuvo lugar, por mis pecados.

Año de 1710 se hizo esta loa en Tlalmanalco, en fiesta que hizo el R.P. cura ministro fray Antonio de la Madrid, a la colocación de una imagen de la Asumpción de Nuestra Señora. Y empieza la loa de San Juan desde donde dice. $\mathbf{N}^{\mathbf{0}} \mathbf{1 3}$.

Hay un error en la numeración del manuscrito: se omite el f. 188 y se pasa directamente del 187 al 189, pero en realidad no falta nada y el texto está completo, sin interrupciones.

Asimismo, en la correlación de los textos se salta del núm. 10 al núm. 13. Parece error, pero no es así, pues una nota manuscrita al final del f. 189r nos advierte que "con las dos de Guadalupe son 13". Sin duda se refiere a las dos loas guadalupanas que, según la "Tabla", se localizarían en los ff. 135145 , las cuales, recuérdese, faltan del manuscrito original. 
-F. 189v: El año de 1706 se hizo este encomio a la festividad del Corpus Christi. $\mathbf{N}^{\mathbf{0}} \mathbf{1 4}$.

-Ff. 189v-190r: Año de 1707 en Nativitas de Tlaxcallan se recitó este elogio a la Natividad de Nuestra Señora. $\mathbf{N}^{\mathbf{0}} \mathbf{1 5}$.

-F. 190r-190v: El año de 6 en un carro se recitó este encomio a Nuestra Señora del Socorro. $\mathbf{N}^{\mathbf{0}} \mathbf{1 6}$.

-Ff. 190v-191r: El año de 1706 se hizo este encomio a la Natividad de Nuestra Señora. $\mathbf{N}^{\mathbf{0}} \mathbf{1 7}$.

-F. 191r: El mismo año se hizo a Nuestra Señora del Socorro en Tlalmanalco. $\mathbf{N}^{\mathbf{0}} \mathbf{1 8}$.

-F. 191r-191v: El año de 1710 se hizo este elogio al Señor y a San Antonio del pueblo de Zoyatzinco. $\mathbf{N}^{\circ} \mathbf{1 9}$.

-F. 191v: El año de 8 se hizo esta canción a Nuestra Señora de Guadalupe, y se ha celebrado mucho. $\mathbf{N}^{\mathbf{0}} \mathbf{2 0}$.

-F. 192r: Versos al glorioso patriarca Señor San Joseph, mi señor. Tlalmanalco, año de 1710. $\mathbf{N}^{\mathbf{0}} 21$.

-F. 192r-192v: Encomio mixto a la festividad del Santísimo Rosario, año de 1713. $\mathbf{N}^{\mathbf{0}} \mathbf{2 2}$.

Tras el último verso se añade una cruz $(\dagger)$ y las siglas S.C.S.M.E.C.R., seguidas de la siguiente declaración: "Y por verdad lo firmo en el pueblo de Amecame, a 17 de septiembre de 1713 años" [dos rúbricas].

-F. 192v: se completa el folio con un diálogo mixto, a dos voces, en castellano y náhuatl, de 25 versos. Es un fragmento que se corresponde (aproximadamente) con los vv. 9-33 del texto citado más arriba con título Apláudese la fineza que el Señor hizo en quedar sacramentado con los hombres (1718).

-F. 193r-193v: Jácara que hice para corregir a un hijo mí. Año de 1713, Meca, a los 13 de agosto de dicho año. $\left[\mathbf{N}^{\mathbf{0}} \mathbf{2 3}\right]^{47}$.

-F. 193v: una protesta de fe cierra este variado conjunto de textos mercurinos: "Todo lo contenido en este Mercurio encomiástico o furor poético, Sujeto a la Correpción de Nuestra Sancta Madre la Iglesia Católica Romana. Y si en éste o en todo lo que hubiere escripto en este idioma se hallare algo disonante a sus sagrados dogmas, lo retrato corregido ${ }^{48}$, tan

47 Es el único ítem del Mercurio encomiástico que queda sin numerar en el manuscrito.

48 "Lo retrato corregido", esto es, 'lo retracto y lo corrijo', según dicta la Iglesia católica. Nótese que la expresión "Sujeto a la Correpción de Nuestra Sancta Madre la Iglesia Católica Romana" coincide con las siglas S.C.S.M.E.C.R. 
obediente como ignorante. Y por verdad lo firmé en el pueblo de Amecame, a los veinte y siete días del mes de octubre de mil setecientos y trece años. Joseph Antonio Pérez de la Fuente y Quijada [firma y rúbrica]".

Debajo aparecen cuatro versos de despedida, en náhuatl ${ }^{49}$.

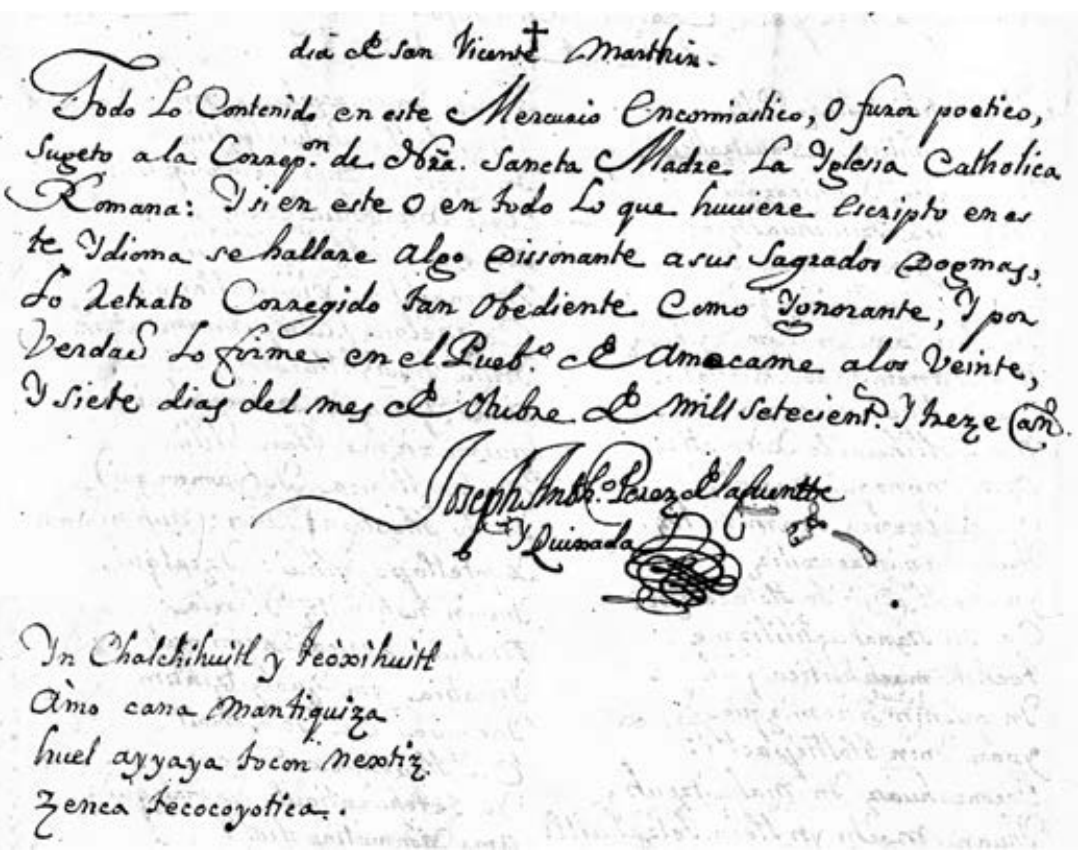

IMAGEN 23. Firestone Library, ms. C0744.02, f. 193v.

Llegan ahora dos folios más, sin numerar, que identifico como 193bis y 193ter.

F. 193bis: las dos caras de este folio contienen la Loa satírica en una comedia en la festividad de el Corpus hecha y recitada en Tlayacapa, año de 1682.

Es el único folio no autógrafo de todo el manuscrito. A mi modo de ver, esto no pone en duda la paternidad de

49 Son los versos que Díaz Cíntora traduce como: "Los jades y las turquesas / no salen por ningún lado; / apenas los extraemos / como coyotes gritamos", y que por supuesto los atribuye a sor Juana (2001, p. 67). Por su parte, Maruri Carrillo los traduce así: "La esmeralda, la turquesa sagrada, / que no se encuentra en ninguna parte, / que no aparece por allá / y que tanto nos aflige" (LoERA 2011, p. 99; 2013, p. 103). 
Pérez de la Fuente de esta Loa satírica. Tampoco hay autógrafos del Quijote o de Inundación castálida -por citar un par de ejemplos- y su autoría no es cuestionada.

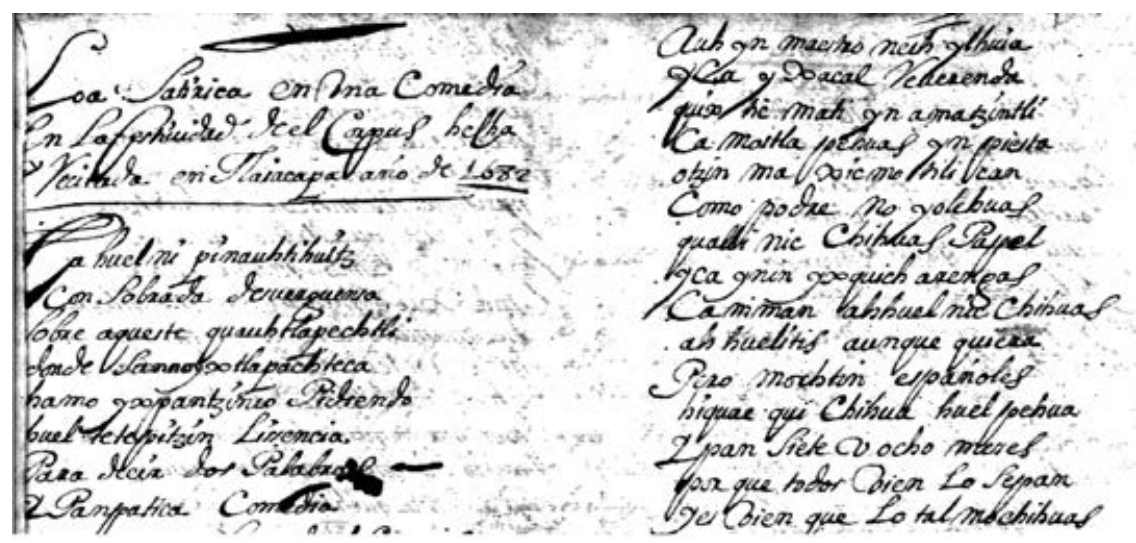

IMAGEN 24. Firestone Library, ms. C0744.02, recto del f. 193bis.

F. 193ter: Capitulo 1 de la incomparable majestad del Sacro Sancto Nombre de Dios, y cuán digno es de ser reverenciado de todos los hombres.

A continuación, el manuscrito ofrece una portadilla interior, en otro folio más sin numerar, de una sección titulada Borradores osiosos y mercurinos traductos del idioma mexicano. Año de MDCCXIII.

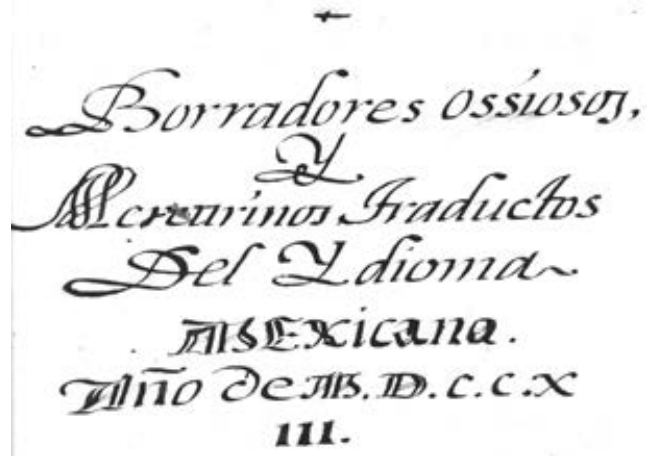

IMAGEN 25. Firestone Library, ms. C0744.02, portadilla interior.

Ff. 194r-199: Ofrecimiento del Rosario de la Virgen María Nuestra Señora. Según se resa en el Convento Real de N. P. Santo Domingo de México. En romance y mexicano. Año de 1713. 
Texto a dos columnas, en náhuatl a la izquierda y en castellano a la derecha. Las oraciones que incluye son:

-F. 194r-194v: Acto de contrición.

-F. 194v: Para lunes y jueves, misterios gososos.

-F. 194v: El segundo misterio de la Visitación.

-Ff. 194v-195r: El tercero misterio del Nacimiento del hijo de Dios.

-F. 195r: El cuarto misterio es de la Presentación del niño Dios.

-F. 195r: El quinto misterio es de el Niño perdido.

-F. 195r-195v: Martes y viernes, misterios dolorosos. El primer misterio es de la oración del huerto.

-F. 195v: El segundo misterio es de los azotes del hijo de Dios.

-F. 195v: El tercero misterio es de la coronación de espinas.

-F. 195v: El cuarto misterio es de la Cruz a cuestas.

-F. 196r: El quinto misterio es de cómo fue crucificado el hijo de Dios.

-F. 196r: Para domingos, miércoles y sábados, misterios gloriosos. El primer misterio es de la Resurrección del hijo de Dios.

-F. 196r: El segundo misterio es de la ascensión del Señor.

-F. 196r: El tercero misterio es de la venida del Espíritu Santo.

-F. 196v: El cuarto misterio es de la Gloriosa Asumpción de Nuestra Señora.

-F. 196v: El quinto misterio es de la Coronación de Nuestra Señora.

-Ff. 196v-197r: Estas oraciones están en el tratado sexto de la Oración vocal, a f. 408. [Incluye el Ángelus y otras oraciones breves].

-Ff. 197r-198v: Estas oraciones son del Libro del perfecto cristiano. [Incluye oraciones varias para cuando se despierta, se levanta, para entrar en la iglesia, tomar agua bendita, etc.]

—F. 199r: El Dios que nos dejaste. En el primer borrador está romanceado.

-F. 199v: Esta oración a las ánimas está en el Ramillete de divinas flores ${ }^{50}$.

50 Podría tratarse de un libro titulado Ramillete de divinas flores para el desengaño de la vida humana. A la Santísima Virgen María. Devotas oraciones y letanías, recopiladas con diligencia de los mejores y más famosos poetas de nuestros tiempos, por P.F.G.C.D. (Amberes, 1629). Con todo, en la época gozó de mayor fama y fue muy reeditado el libro de Bernardo Sierra, Ramillete de divinas flores. Escogidas en las obras de muchos santos y mejores autores que las han escrito y observado, en aumento del delicioso jardín de la Iglesia, atadas en este ramillete, con múltiples ediciones: 1670, 1672, 1718, 1740, 1743, 1744, 1769, 1775. 
-Ff. 200r-207v: Marzo, San Policronio, 17 de 1709, Tlaxcallan. El texto de la doctrina. Traducido al idioma mexicano.

Hay un error en la numeración de los folios, pues el 203 se repite dos veces, así que en realidad esta sección ocupa nueve folios y no ocho. Traduce al náhuatl oraciones varias como el Padrenuestro, Ave María, Credo, la Salve, una bendición de la mesa, los Mandamientos de la ley, etcétera.

En la "Tabla" inicial, a esta parte se la llama simplemente: "La Cartilla con todas las oraciones".

En el f. 203r se lee: "En este presente año de mill setecientos y 10 se halla este reino perdido, si no acabado, por las cosas siguientes: por el poco temor sancto que a Dios se tiene; poquísima devoción; y porque no hay justicia”.

En el reverso del f. 203bis firma como "El Mercurio Mexicano", con su rúbrica, y añade este comentario: "Prosíguense las curiosas traducciones examinando la lengua mexicana por el Arte que tengo hecho y titulo Mercurio mexicano. No por otra razón que ser voluntad del Señor, lo primero; y lo segundo saber dónde tiene este idioma sus dificultades y hasta dónde llegan sus primores. Meca, y abril 28 de 1713 años, con advertencia que desde el año de 92 hasta hoy se ha venido acallando la lengua mexicana, en tal modo que no se conoce sino muy poca en estos tiempos, porque los indios se llaman, porque el etc.”.



IMAGEN 26. Firestone Library, ms. C0744.02, reverso del f. 203 bis. 
En el f. 207r hallamos el siguiente comentario del autor: "Con esto se acabó toda la traducción del Catecismo de la doctrina, para cuyo efecto se comenzó a trabajar en el idioma mexicano desde 26 de septiembre de 1666 años. Y por verdad lo firmo hoy, miércoles 3 de mayo de 1713 años, que ha 47 años que harán por [abreviatura]. S.C.S.M.E.C.R. Amecamecan, día de la Santa Cruz. Joseph Antonio Pérez de la Fuente [firma y rúbrica]".

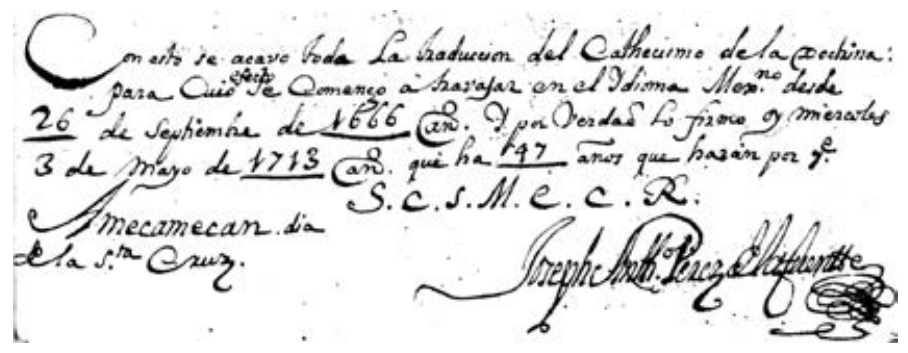

IMAGEN 27. Firestone Library, ms. C0744.02, f. 207 r.

En el f. 207v leemos este otro aviso: "Para honra y gloria de Dios y de la Sanctísima Virgen MARÍA, Nuestra Señora, se acabó esta fábrica en el pueblo de Amecamecan, de la Provincia de Chalco, en tres días del mes de mayo de mil setecientos y trece años, día de la Sancta Cruz, habiendo durado cuarenta y siete años, siete meses y siete días, que esos desde 26 de septiembre de 1666 hasta tres de mayo de 1713 se cuentan. Y todo lo sujeto a la corrección de Nuestra Santa Madre la Iglesia Católica Romana, y si en ello se hallare algo disonante a sus sagrados dogmas, lo retrato corregido, tan obediente como ignorante, y por verdad lo firmo en dicho pueblo, dicho día y año dicho. Joseph Antonio Pérez de la Fuente [firma y rúbrica]". 


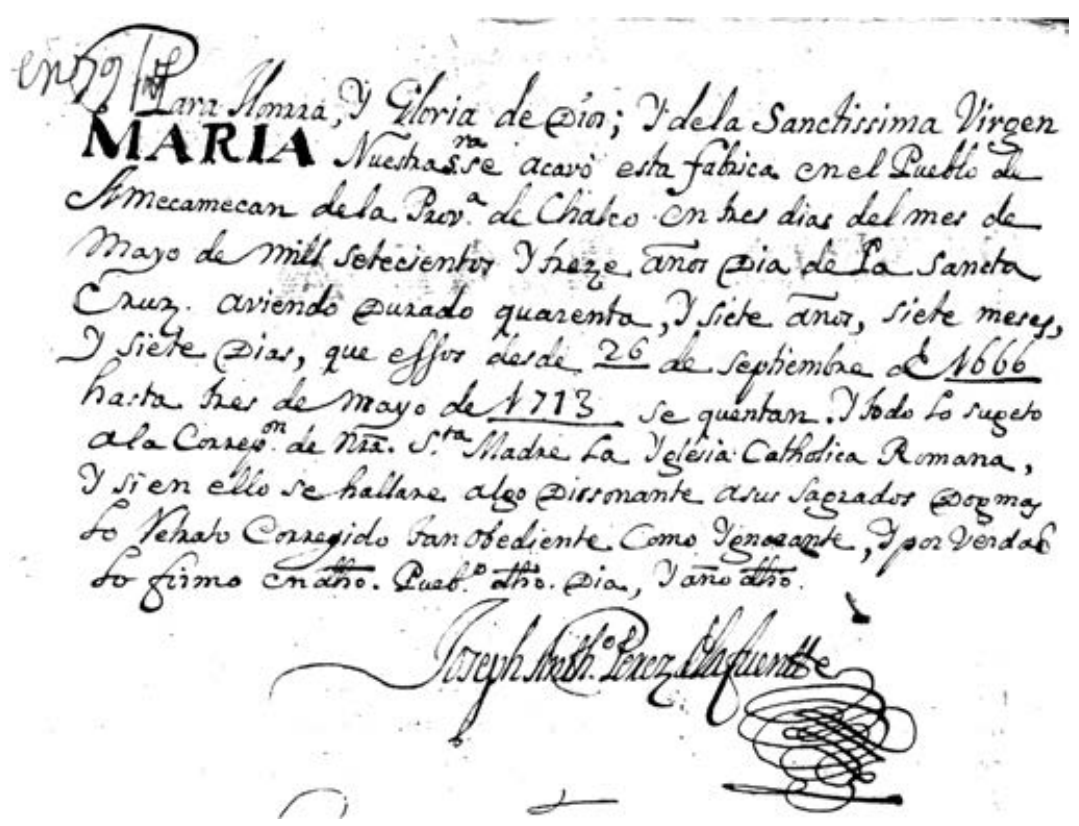

IMAGEN 28. Firestone Library, Ms. C0744.02, f. $207 v$.

Sigue un folio de guarda en blanco, sin numerar, que cierra la sección de los Borradores osiosos. A continuación, vienen dos folios más, sin numerar, que llamo 209 y 210.

-F. 209r: Oración a el Spíritu Santo. Mayo, diez y nueve de 1709, Tlalmanalco. Domingo, Pascua del Espíritu Santo, que nos valga.

Una rúbrica. Texto en náhuatl.

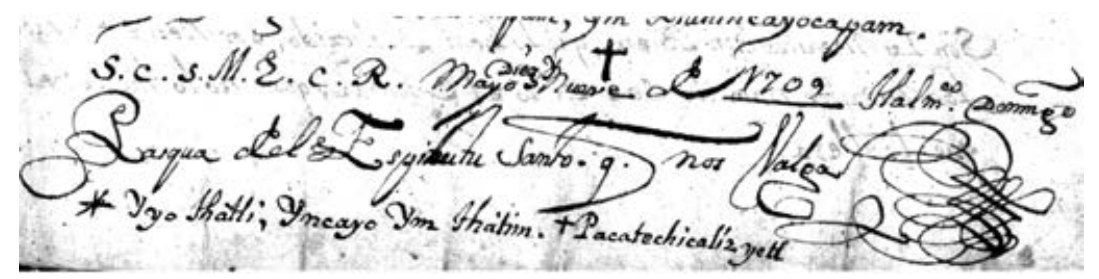

IMAGEN 29. Firestone Library, ms. C0744.02, f. 209 r.

-F. 209v: Conceptos políticos y muy útiles, morales. Texto en castellano.

-F. 210r: Pater de Celis Deus, miserere nobis. Tlalmanalco, y mayo 21, martes, de 1709. Último día de Pascua del Spíritu Santo. Texto en náhuatl. 
-F. 210v: distintas cifras y tablas numéricas.

Por último, una hoja de guarda, con letras y números en sucio, que sirve para el cosido final y encuadernación de todo el manuscrito.

\subsection{Una loa satírica (1682) y una loa sacramental (1718)}

De todo este amplio corpus sólo voy a examinar brevemente un par de textos: la Loa satírica de 1682 (f. 193bis) y la loa sacramental de 1718 (ff. 182bis-182ter). Según he avanzado páginas atrás, ambas loas se publicaron como una sola a nombre de sor Juana, primero por Díaz Cíntora y Vallejo Villa (2001) y después por Loera (2011). El manuscrito parisino ("Mexicain 303") ya ofrecía pistas certeras de quién era su autor, aunque fueron pasadas por alto. La puesta en circulación ahora del manuscrito de la Firestone Library en Princeton (C0744.02, núm. 10), donde reaparecen ambos textos, aleja cualquier resquicio de duda sobre su autoría.

Sí me interesa destacar que ni una ni otra loas pertenecen al Mercurio encomiástico ${ }^{51}$. Este variado corpus de piezas teatrales breves (loas, encomios, elogios, cantos...) contiene 21 ítems; la serie numérica alcanza hasta el 23, pero faltan dos loas dedicadas a la Virgen de Guadalupe (teóricos núms. 11 y 12) que siguen ilocalizables. Los 21 textos mercurinos que se leen en el manuscrito de Princeton aparecen tal cual en la copia de París que hizo Pichardo. El fin de la serie queda bien marcado por el aviso de que "Todo lo contenido en este Mercurio encomiástico o furor poético, Sujeto a la Correpción de Nuestra Sancta Madre la Iglesia Católica Romana” (f. 193v). Es una típica protesta de fe (en el sentido de 'promesa, aseveración firme') de las que tanto abundaban en los escritos católicos de toda índole, en Europa y en América $\left(\right.$ García 2009) ${ }^{52}$. Los autores se someten al superior dictado de la Iglesia y aceptan cualquier enmienda que ésta pueda sugerir,

${ }^{51}$ La mención de "Mercurio" en los títulos, padre de la elocuencia que fue heraldo o mensajero de los dioses, ya gozaba de una amplia tradición literaria: véase el Mercurio de Arias de Villalobos (1623), el Mercurio Volante de Sigüenza y Góngora (1693) o el Mercurio Indiano de Patricio Antonio López (1740), que son antecedentes de famosos periódicos como el Mercurio Histórico y Político, el Mercurio Peruano, el Mercurio de Chile, etc. El adjetivo "encomiástico" remite directamente al carácter elogioso de las piezas dramáticas que lo integran, donde abundan las loas y los encomios.

52 Díaz Cíntora, que parece no conocer la terminología exacta, la llama "fórmula de sujeción" (2001, p. 67). 
llegando a veces a pedir perdón por anticipado caso de haber atentado involuntariamente contra el dogma. Es de notar cómo las piezas cortas del Mercurio encomiástico abrazan una cronología bastante homogénea (aunque no sigan una linealidad perfecta en el tiempo), que a grandes trazos discurre desde 1682 (el primer encomio) hasta 1713 (la última jácara). Y lo que es más importante, hay unidad temática, tonal o de intención en estas obras mercurinas, pues todas ellas son de tema sacro o religioso. Predominan las loas marianas o encomios a la Virgen en cualquiera de sus fiestas o advocaciones, con once textos (núms. 2-6, $9,15-18$ y 20). Otros cinco se dedican a distintos santos, por sus festividades: Santiago (7), San Juan Bautista (8), San Luis Obispo (10), San Antonio, patrón del pueblo de Zoyatzinco (19), y al Patriarca San José (21). Dos loas más son de las llamadas sacramentales, escritas ex profeso para la festividad del Corpus Christi (1 y 14). Las tres restantes son de asuntos variados: a la dedicación de un templo a la Virgen de Guadalupe (13), a la fiesta del Rosario (22) y, por último, una Jácara que hice para corregir a un hijo mio (23). Esta jácara entra en el tema sacro (una especie de jácara a lo divino) por el tono aleccionador y catequético con que Pérez de la Fuente amonesta a su hijo (sobre el texto en náhuatl, destaca la palabra "Dios" escrita siempre en castellano).

Insisto en que la Loa satírica en una comedia en la festividad de el Corpus hecha y recitada en Tlayacapa, año de 1682 queda fuera del ámbito mercurino y se aparta por completo de su línea temática: es una loa profana, en clave cómico-satírica, que sirve de antesala a la comedia (no se dice el título) que se dispone a ver el público de Tlayacapan. Destaca por su gracejo y sentido del humor, y sobre todo por reivindicar la capacidad de los indios -tan denostada por los españoles- para el arte histriónico: se habla de cómo llevan cuatro días ensayando, seguramente niños actores del pueblo, pues se dice que van a la escuela ${ }^{53}$. La pieza concluye con la típica petición de benevolencia por las faltas que los actores puedan cometer. El texto orbita alrededor de lo cómico y lo satírico, pero de ningún modo es una loa sacramental dedicada a la Eucaristía (Corpus Christi). Para celebrar las fiestas del Corpus se solía echar mano de un auto sacramental (lo propio de ese día), pero el gusto por el teatro en la época era tan intenso que, cuando no era posible conseguir un auto, muy a menudo se recurría a una comedia cualquiera, sin

${ }^{53}$ Recuérdese que nuestro dramaturgo regentó una escuela de niños en Ayapango: véase supra, apartado 2. 
conexión alguna con el motivo eucarístico. Esto es exactamente lo que pasa aquí: se juntaron una loa satírica de Pérez de la Fuente y una innominada comedia para entretener en las fiestas del Corpus a los habitantes de Tlayacapan, indígenas en su mayor parte, allá por el año de 1682. Todo ello en perfecta mezcla de lo humano (sátira, risa, comedia) con lo divino (Corpus Christi), nada que no se hubiera hecho cientos de veces antes y después, tanto en España como en cualquiera de sus virreinatos.

El otro texto que ahora nos afecta, Apláudese la fineza que el Señor hizo en quedar sacramentado con los hombres, sí entra de lleno en la categoría de las loas sacramentales. Por eso es absurdo e incoherente unir ambas loas y editarlas como una sola (Díaz Cíntora 2001, pp. 72-78; Loera 2011, pp. 125-129, 174-179, 193206), amén de que entre ambas composiciones media un abismo de 36 años. Adentrándonos en el texto, vemos que la Música inicial invita a que

La mayor fineza el orbe
en dulces cadencias cante,
y en obsequios reverentes
rinda gratitudes leales

(f. 182bis $)^{54}$.

Tras esta llamada general a la obsequiosidad y reverencia, empieza una típica loa competencial donde un Indio y un Español disputan por ver quién es más digno de alabar el misterio eucarístico (Zugasti, 2008, p. 311) ${ }^{55}$. Pero el tema (y la teología) impiden llevar más allá las diferencias entre uno y otro (Cristo redime a todos los hombres por igual), así que no tardarán mucho en sumar sus voces (alternarlas es más correcto) en honor a la Eucaristía:

54 Cita en español en el manuscrito. Loera (2011, p. 200) edita mal, "La mayor fineza del orbe / en dulces cadencias cante", de modo que no se sabe quién es el sujeto cantante. En realidad, los versos dicen que es el orbe (sujeto gramatical) quien ha de cantar en dulces cadencias la mayor fineza (de Cristo).

${ }^{55}$ La Iglesia puso serios reparos a que los indios entonaran sus propios cánticos. El concilio I Mexicano (1555, cap. 72) decretó que "los indios no canten cantares de sus ritos e historias antiguas, sin que primero sean examinados los dichos cantares por religiosos o personas que entiendan muy bien la lengua, y en los tales cantares se procure por los ministros del Evangelio que no se canten en ellos cosas profanas. Más decisivo dice el de 1585, prohibiendo totalmente los cánticos del tiempo de su gentilidad, y permitiendo solamente los que los párrocos y vicarios les aprobasen" (CABRERA y Quintero 1746, p. 373). 
Y pues son tan eficaces tus razones, me conformo con tu afecto y tu dictamen; y pues esto te ha traído a sólo desempeñarte y estamos los dos aquí, con elogios festivales rindamos las alabanzas a este misterio inefable, y en alternados acentos se publiquen los quilates de la fineza mayor que se ha visto ni ha de hallarse, porque aqueste sacro arcano es un piélago insondable

$$
\text { (f. 182bis). }
$$

El Indio destaca el prodigio de la Encarnación y el Español pondera más el de la Eucaristía, merced al cual Cristo permanece entre los hombres: “¿Qué más prueba / de una fineza tan grande / que es quedar sacramentado / para jamás apartarse / de nosotros?" (f. 182bis). El alimento eucarístico lo asocia el Indio con el milagro de la multiplicación de los panes y los peces (Jn 6:1-15; Lc 9:12-17); el Español zanja el debate asumiendo que "quedamos / en esta cuestión iguales"; el Indio está de acuerdo y ambos cierran la loa alternando sus loores al misterio inefable del Santísimo Sacramento.

\section{LA ERRÁticA ATRIBUCIÓN DE LA LOA INFANTIL DE SOR JUANA}

En 2001, el historiador Augusto Vallejo Villa consultó en la Biblioteca Nacional de Antropología e Historia el microfilm del Mercurio encomiástico (al parecer sólo los folios 40-51, pues del resto no dice nada $)^{56}$. Confiesa que este título "me pareció muy sugestivo" y de inmediato

tuve en mente la Loa que sor Juana había compuesto en la hacienda de Panoayan, perteneciente a la jurisdicción de esta población, a la edad de ocho años, según el padre Calleja. Siempre supuse que, si la llegó a escribir, estaría en náhuatl, pensando que Amecameca era un pueblo predominantemente de indios (pp. 80-81).

${ }^{56}$ El microfilm, recuérdese, es reproducción parcial del ms. "Mexicain 303" que se custodia en la Biblioteca Nacional de Francia. 
Esto es, a partir de una obra en náhuatl de título sugestivo, se da un salto a la suposición de que quizás podría ser la perdida loa infantil de sor Juana. Para corroborar su pálpito observa que el indio principal de Tlayacapan que se cita en el f. 40v, don Juan Hipólito Cortés Quetzalquauhtli y Tequantepehua, está registrado en el Archivo General de la Nación desde 1656 por una sentencia que se emitió en su contra (AGN, Indios, vol. 20, exp. 198, f. 148). Del mismo modo, documenta la presencia de Pérez de la Fuente en dicha zona, a partir de otro pleito de 1693, donde un testigo declara que "se ha avecindado un mestizo achinado llamado Joseph Pérez de [la] Fuente, quien les hace [a los indios] escritos y los aconseja e industria"

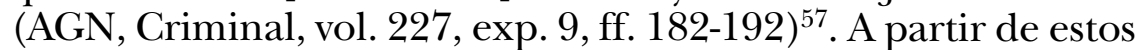
datos, Vallejo Villa asume que Pérez de la Fuente "para la segunda década del siglo XviII se encuentra ya en Amecameca y recopila el Mercurio encomiástico, incluyendo al final la Loa satírica" (p. 81). Hay dos cosas -justificables ambas- que Vallejo Villa deduce erróneamente del microfilm: $a$ ) que la orden del indio principal Juan Hipólito Cortés de hacer y recitar una obra teatral en Tlayacapan durante el Corpus Christi de 1682 afecta a todo el Mercurio encomiástico, con sus veinte ítems, cuando en verdad sólo atañe al primero de ellos, el Encomio al Santísimo Sacramento; b) considera que la Loa satírica que captó su atención se integra en el citado Mercurio encomiástico, pero no es así, pues este corpus teatral se caracteriza por su temática sacra, y esta loa satírico-cómica queda fuera de dicho ámbito. Consecuencias más graves tiene el hecho de asumir de plano que Pérez de la Fuente es un simple recopilador de textos ajenos (sin plantearse siquiera la posibilidad de que fuera el verdadero autor) y, sobre esta premisa, construir el quimérico edificio sorjuanino:

$\mathrm{Al}$ analizar este documento me percaté de que decía que se hizo y se recitó en Tlayacapan el año de 1682; noté que, sin embargo, el manuscrito mencionaba Amecameca, hablaba de Medea, de una abuela, de negros y de novillos de la hacienda. Estas palabras en español, entresacadas de la parte del náhuatl, me hicieron creer que mi sospecha podría tener fundamento y ser la composición de Sor Juana que menciona su biógrafo, la cual fue escrita cuando tenía ocho años (p. 81).

Vemos con asombro cómo la sospecha inicial de Vallejo (un a priori) se transforma en certeza por arte de birlibirloque, a

57 Es el documento que hemos citado supra, apartado 2. 
base de agrupar datos del texto que, convenientemente dirigidos, apunten hacia la Décima Musa. Así, apelaciones a la bruja Medea (v. 66), a una negra tiznada (v. 83) y a los novillos de una hacienda (v. 86), o menciones al lugar de Amecameca (v. 92) y a una abuela (v. 114), se convierten para Vallejo en evidencias absolutas de que se trata de la loa infantil de Inés de Asuaje, ¡como si en la Amecameca del siglo XviI no hubiese habido más negras, más haciendas de ganado y más abuelas que las de sor Juana! La loa también nombra otros lugares como China (v. 91) y Atenas (v. 96), los cuales no llaman la atención del historiador $^{58}$. La negra tiznada no va más allá de un típico insulto de época, y la cita de la abuela es genérica, impersonal y enfática; los versos "iMi abuela / puede sufrirlo, por cierto, / que gasta muy linda flema!" (vv. 114-116) no se refieren a una abuela concreta, ni a la de sor Juana ni a ninguna otra.

Estamos ante un claro ejemplo de lectura distorsionada que da la espalda al sentido recto del texto y lo dirige hacia un objetivo concreto: adecuarlo a un molde preconcebido, esto es, encajarlo como sea dentro del zapato de sor Juana. Nada que no haya pasado antes en repetidas ocasiones en el ámbito de la crítica y la hermenéutica, aquí además con el agravante de que el artículo de Vallejo arrastra y condiciona el trabajo contiguo de Díaz Cíntora. Para reconducir este tipo de interpretaciones sesgadas disponemos de un poderoso antídoto: la filología, siempre que sea utilizada a cabalidad y con sindéresis.

Dicho esto, el mayor problema del artículo de marras está por llegar. Me refiero a la manipulación consciente de los datos textuales con el ánimo de falsear la realidad. Veamos el proceso. Dado que Vallejo ya decidió en su fuero interno que está ante la loa infantil de sor Juana, ahora sólo resta acomodar a conveniencia la fecha del texto: "La abuela, que se menciona por Sor Juana en la Loa, murió entre el 3 y 8 de octubre de 1657, por lo que esta obra debió de representarse en 1656 o 1657" (p. 81). No importa que el título diga Loa satírica en una comedia en la festividad del Corpus hecha y recitada en Tlayacapan, año de 1682; Vallejo asienta que "de entrada este título es inexacto", basándose en el peregrino argumento de "que la obra fuera hecha en Tlayacapan es

58 Al respecto, comenta Poot Herrera: "La mención de Amecameca en el primer poema hace suponer [a Vallejo] que allí se escribió y representó originalmente la loa (los dos poemas). ¿Qué decir de la China que también se menciona una línea antes?” (2005, p. 293). Con fina ironía, SoRIANo VAllés añade que "cuatro versos después aparece la ciudad de Atenas" (2010, p. 72). 
desmentido al mencionar Amecameca como lugar de la representación de la Loa" (p. 119). He aquí cómo una ocasional mención a Amecameca (el pasaje dice simplemente que "en público se arrodillan / poniendo el un pie en la China / y el otro en Amecameca", vv. 90-92) se transforma por arte de magia en el espacio de representación; he aquí cómo la fecha de 1682 se retrotrae a 1656 o 1657 para ajustarla a la muerte de la abuela de la Décima Musa; he aquí cómo se ignora a un autor poco conocido (Pérez de la Fuente) y se le rebaja a la categoría de mero recopilador o copista; he aquí cómo una Loa satírica en una comedia en la festividad del Corpus hecha y recitada en Tlayacapan, año de 1682 pasa a editarse y traducirse como una Loa satírica mixta de una comedia representada en el atrio de la iglesia del convento dominico de Nuestra Señora de la Asunción de Amecameca en la festividad del Corpus Christi (Díaz Cíntora 2001, pp. 72-75).

Son cambios tan injustificados y burdos que es imposible hacerlos derivar de una mala interpretación: todo lo del atrio conventual en Amecameca es inventado ex profeso. Pero es que aún hay más. Estamos hablando todo el rato de una loa satírica en singular, y lo que en verdad Vallejo Villa y Díaz Cíntora nos brindan son dos loas. Ellos sostienen que se trata de una sola loa en dos partes: "A la parte propiamente satírica, de 160 versos..., sigue otra, seria y sin asomo ya de sátira..., de 170 versos" (Díaz Cíntora 2001, p. 67). Las cosas, de nuevo, tampoco son así. Han fundido dos loas distintas, copiadas por el padre Pichardo en folios consecutivos (49, 50 y 51), en una sola. Para ello han hecho caso omiso - una vez más- del título original que consta en el manuscrito para este segundo ítem: Apláudese la fineza que el Señor hizo en quedar sacramentado con los hombres. Año de 1718. Vallejo Villa vuelve a exhibir sus artes de prestidigitador y afirma que "esta fecha me parece un error o confusión del amanuense" (p. 119). Vano empeño de fusionar dos textos en uno y retrotraer ahora la fecha de 1718 hasta 1656 o 1657, sin justificación posible (pero valga todo ello para adecuarlo a la cronología sorjuanina).

Sí es digno de aplauso el mérito de Díaz Cíntora de traducir del náhuatl al castellano dos textos teatrales que hasta 2001 contaron -si acaso- con muy pocos lectores ${ }^{59}$. Pero la onda

59 Útiles son también los asertos de este mismo crítico sobre el uso del náhuatl a manos de sor Juana (DíAz CínTora 2005), con la salvedad de que todo lo referente a la Loa satírica y el verso "Yoqui in tlahuépoch Medea" (traducción: 'como la bruja Medea') hay que readjudicarlo al buen mestizo Joseph Pérez de la Fuente. 
expansiva de esta errática atribución sorjuanina, con el apoyo de prensa, radio y televisión, tuvo consecuencias. Tras la muerte de Díaz Cíntora (2004), su sucesor en la Academia Mexicana de la Lengua, Serrano Migallón, en el discurso de ingreso, hizo los debidos elogios al recién desaparecido filólogo y destacó por encima de todo que fue él quien "identificó y autentificó el más antiguo de los trabajos literarios de Sor Juana Inés de la Cruz, la llamada Loa de infancia" (2006, p. 4). En la misma línea, Enrique Flores (2007) da por bueno el hallazgo y analiza la obra como pieza segura de la monja jerónima. No es mi intención inventariar aquí todos los desvíos críticos derivados de Vallejo Villa y Díaz Cíntora, pero sí ameritan algún comentario los prolijos escritos de Margarita Loera Chávez y Peniche (2011 y 2013).

Esta historiadora, en su libro Flor de volcanes. Sor Juana Inés de la Cruz: vida y obra en la región donde nació, da marchamo de autenticidad a los dos errores básicos que ya urge desterrar del panorama crítico: la autoría de sor Juana y el empeño en conectar dos loas, que distan entre sí 36 años, como si ambas fueran una misma cosa. El principal damnificado de este apriorismo es nuestro mestizo Pérez de la Fuente, reducido a simple copista (hay larga tradición en esto, como se ha dicho) y cuya caligrafía parece confundirse con la del padre José Pichardo ${ }^{60}$. Por si esto fuera poco, se le arrebata la paternidad de las otras loas del Mercurio encomiástico, las cuales "parecen haber sido autoría de caciques e indios principales" (p. 9), idea que se reitera más adelante: "los textos pudieron haberlos requerido autoridades religiosas locales a indios nobles que estudiaban en las escuelas conventuales" (p. 91) ${ }^{61}$.

$\mathrm{Al}$ aplicar la lente sorjuanina al estudio e interpretación de los versos que son eje del libro, Loera insiste hasta la saciedad en su inherente criollismo, en su orgullo criollo: ¿cómo lidiar ahora con este concepto, cuando sabemos a ciencia cierta que su autor es un mestizo? Los titánicos esfuerzos por fusionar dos loas diferentes en una son dignos de mejor causa: "se trata de dos loas con un mismo argumento" (p. 8), ambos textos "cons-

60 A propósito del manuscrito "Mexicain 303" de la BNF, dice LoERA que "todo el corpus documental en que se encuentra el documento atribuido a sor Juana lo reprodujo este personaje, como se constató después de la paleografía y traducción de toda la serie documental" (2011, p. 80).

${ }^{61}$ LoERA persiste en el error en otro escrito más tardío: "Estas [20 piezas] fueron escritas en lengua náhuatl por caciques indios de la región en estudio y presentan un claro disfraz en su contenido" (2013, pp. 89-90). 
tituyen una unidad" (p. 78). No hay tal: la primera es una loa de presentación de una comedia escrita en 1682 y la segunda es una loa sacramental de 1718 (Loera se empecina en llamarla una y otra vez "auto sacramental" o -peor aún- "intento de auto sacramental"). Lo más grave, a mi modo de ver, es que fruto de este desenfoque deviene una lectura que atenta contra la literalidad de los textos. Ya sabemos que el muy devoto Pérez de la Fuente escribió múltiples encomios, loas, jácaras... para conmemorar diferentes fiestas de culto mariano, a los santos o al Corpus Christi. Esto no desalienta a Loera, que en una fantástica pirueta retórica da la espalda al transparente sentido literal y los convierte en obras de resistencia y reivindicación de los ritos prehispánicos:

El objetivo era ensayarlos para luego recitarlos en festividades católicas en los atrios de las iglesias locales, con la finalidad de mostrarles a los macehuales o indios del común cómo se realizaban entonces los rituales en honor de la montaña, los volcanes y las deidades o fuerzas sobrenaturales que creían que habitaban en ellos. Sin discusión, era un acto de resistencia y un medio de guardar su memoria ancestral (p. 9).

Margarita Loera tiene especial apego a este enfoque transgresor y posmoderno, donde la libérrima interpretación de un texto vuela por encima de su coherencia semántica. Para ella, toda sor Juana puede leerse en esta clave: "Es muy notorio ese juego tan característico de la Décima Musa en el que detrás de un acto de humildad deja aparecer un tono de soberbia o de confrontación al orden establecido" (p. 104). Así que, extrapolando este concepto a las loas que le ocupan, descubre en ellas un mensaje oculto, un doble lenguaje, un "difrasismo en el que tras un aparente discurso dirigido a las vírgenes $[s i c]$ o a los santos cristianos se esconde un discurso didáctico sobre las formas de culto a la montaña” (p. 93). ¡Ahí es nada! Pérez de la Fuente palidecería ante tamaño dislate. Sus poéticas evocaciones en náhuatl de jades y turquesas pasan a ser ecos (malintencionados, por supuesto) de ofrendas rituales de los indios "para lograr el verdor de la naturaleza y la bonanza de las lluvias... a la usanza mesoamericana", en "un difrasismo que oculta contenidos religiosos sincréticos" (p. 93). Entre los varios ejemplos que se aducen está la Jácara que hice para corregir a un hijo mío, donde el autor llama a su vástago "amado y precioso jade sagrado, 
piedra preciosa, mi collar de flores..." (p. 95). Estas expresiones y otras afines se despojan de todo lirismo y carga afectiva, para adivinar en ellas arcanos profundos y telúricos. De modo que el náhuatl que utiliza este mestizo ilustrado y bilingüe en unas piezas dramáticas cortas dirigidas a los indios de los pueblos de la región de Chalco, ese discurso en náhuatl, al decir de Loera, "oculta un mensaje sin relación alguna con lo que se diría en una fórmula literaria de corte hispano" (p. 93), ese náhuatl "no corresponde a lo prometido en los títulos" (p. 92) y en realidad esconde "la intención del contenido" (p. 93).

Los prejuicios ideológicos y el desprecio absoluto al sentido literal de los textos (el primer e insoslayable -aunque no el único- nivel de lectura) propician este alejamiento radical de la primigenia intención del autor. ¿Qué hacer entonces con las múltiples protestas de fe que Pérez de la Fuente siembra por su manuscrito sometiéndose al juicio de la Iglesia católica? No es motivo para el desaliento; Loera da por sentado que late ahí "un tono de cierto cinismo" (p. 93) que desactiva su mensaje y -deduzco- le hace decir lo contrario de lo que cualquier simple mortal lee y entiende. Por eso se atreve a afirmar que la primera loa "habla de la festividad de Corpus Christi en forma altamente satírica" (p. 99), cuando en realidad dicha pieza ni es sacramental ni aborda el tema eucarístico; pero la segunda loa sí es sacramental y la contundencia de su mensaje es más difícil de eludir; difícil pero no imposible, claro, pues para esta historiadora ahí "se escondía el culto indio en el cristianismo y la resistencia a la evangelización” (p. 141).

Loera insiste en el valor sincrético de estas loas, lo cual es verdad, siempre y cuando pongamos el sincretismo en su justo punto, esto es, en la emisión de un mensaje nuclear (aquí sin duda el de la fe católica) bajo un revestimiento bilingüe náhuatlespañol que busca acercarse lo más posible al horizonte de comprensión de los espectadores, en su mayoría aborígenes de la región de Chalco. Nada más sincrético que un mestizo letrado y cristiano como Pérez de la Fuente. Según entiendo, sincretismo no es ecumenismo, ni tampoco maridaje perfecto entre ritos o credos, y mucho menos preponderancia subliminal de un discurso oculto (náhualt-azteca) sobre otro aparente y superficial que hay que relegar (español-católico). Sincretismo tampoco es dar pábulo a las etimologías populares, como hace Loera con la segunda loa (Apláudese la fineza que el Señor hizo en quedar sacramentado con los hombres), donde el canto al Santísimo Sacramento se 
metamorfosea según las gentes del lugar en el canto al Señor del Sacromonte, asentando que la loa "alude constantemente al culto a la montaña y al agua" (p. 61), pues "resulta claro que detrás de la figura de Jesucristo, en este caso muy probablemente el Señor del Sacromonte, está el escudo de jade que simboliza las deidades del agua a las cuales en la época prehispánica se rendía culto en ese lugar" (p. 142). Difícil desbarrar más en menos páginas.

En lo que al manejo de materiales de archivo se refiere, esta Flor de volcanes tiene un acierto y dos fallos. El acierto mayor es atender el expediente criminal abierto a Pérez de la Fuente en 1693 por inquietar los pueblos y haciendas de la provincia de Chalco (citado por Vallejo Villa: AGN, Criminal, vol. 227, expediente 9, ff. 183-192). Ahí tenía la historiadora en la punta de los dedos al verdadero autor de las loas, pero su obcecación por adjudicárselas a sor Juana le impidió verlo. El fallo reside en entremezclar este documento con otro sobre pleitos de tierras en Amecameca (AGN, Tierras, 994, ff. 16-124) valorando la posibilidad de que Pérez de la Fuente estuviera implicado en el mismo (pp. 80-81). Idea baladí y fácilmente refutable, habida cuenta de que este segundo documento data de los años 1779-1780, demasiado tardío para que nuestro mestizo siguiera con vida. El segundo fallo consiste en desempolvar del mismo Archivo General de la Nación cierto documento inédito en el que "se observa cómo desde la etapa del convento sor Juana continuaba manteniendo relaciones importantes en la región de los volcanes" (p. 26). La síntesis de este documento se ofrece en las pp. 207-215, pero hay un pequeño problema, apenas una nadería..., y es que la monja a la que se refiere no es sor Juana Inés de la Cruz, sino otra hermana jerónima llamada Juana de Santa Inés ${ }^{62}$.

Mérito del libro es la implicación de la maestra María Elena Maruri Carrillo en la tarea de traducir los textos del náhuatl al castellano, en complemento con lo iniciado por Faustino Galicia, Dávila Garibi (véase Ballinger 1951) y Díaz Cíntora. Se anuncia un segundo volumen con las traducciones de todo el Mercurio encomiástico, lo cual sería muy de agradecer, pues allanaría el acceso a estas obras, legibles hoy en su totalidad sólo por nahuatlatos. Obvia decir que semejante tarea hay que acometerla a partir de los textos autógrafos de Pérez de la Fuente que he localizado en

62 Por el Libro de profesiones del convento de San Jerónimo de México sabemos que esta monja profesó el 26 de noviembre de 1641 y murió el 24 de enero de 1701 (Schmidhuber de la Mora 2013, p. 165). 
Princeton y desterrando para siempre cualquier contaminación autorial con sor Juana Inés de la Cruz, la cual luce galana por sí sola sin necesidad de que se le prohíjen obras ajenas.

\section{Conclusiones}

Culmino esta investigación con unas tablas donde paso inventario a la obra conservada de Joseph Antonio Pérez de la Fuente, distinguiendo entre sus textos originales y las traducciones. Dejo asimismo constancia de las bibliotecas que custodian sus manuscritos.

\section{TABLA 1}

\begin{tabular}{|c|c|c|c|c|c|}
\hline & Obras originales - Títulos & Princeton & Paris & $\begin{array}{l}\text { New } \\
\text { York }\end{array}$ & México \\
\hline & Relación mercurina (bilingüe) & $\mathrm{X}$ & $\mathrm{X}$ & & \\
\hline & Apláudese la fineza que el Señor hizo & $\mathrm{X}$ & $\mathrm{X}$ & & \\
\hline & Jácara que cantó un moderno & $\mathrm{X}$ & $\mathrm{X}$ & & \\
\hline M & Encomio al Santísimo Sacramento & $\mathrm{X}$ & $\mathrm{X}$ & & $\mathrm{X}$ \\
\hline $\mathrm{E}$ & Loa a la Santísima Virgen & $\mathrm{X}$ & $\mathrm{X}$ & & $\mathrm{X}$ \\
\hline $\mathrm{R}$ & Loa a la Santísima Virgen (con variantes) & $\mathrm{X}$ & $\mathrm{X}$ & & \\
\hline C & Loa a la Santísima Virgen (con variantes) & $\mathrm{X}$ & $\mathrm{X}$ & & \\
\hline $\mathrm{U}$ & Loa a la Asumpción de Nuestra Señora & $\mathrm{X}$ & $\mathrm{X}$ & & $\mathrm{X}$ \\
\hline $\mathrm{R}$ & Encomio a la Asumpción de Nuestra Señora & $\mathrm{X}$ & $\mathrm{X}$ & & \\
\hline $\mathrm{I}$ & Encomio a Santiago & $\mathrm{X}$ & $\mathrm{X}$ & & \\
\hline \multirow[t]{2}{*}{$\mathrm{O}$} & Elogio a San Juan Baptista & $\mathrm{X}$ & $\mathrm{X}$ & & \\
\hline & Elogio a Nuestra Señora de los Remedios & $\mathrm{X}$ & $\mathrm{X}$ & & \\
\hline $\mathrm{E}$ & Elogio a San Luis Obispo & $\mathrm{X}$ & $\mathrm{X}$ & & \\
\hline $\mathrm{N}$ & Loa de San Juan & $\mathrm{X}$ & $\mathrm{X}$ & & \\
\hline $\mathrm{C}$ & Encomio al Corpus Christi & $\mathrm{X}$ & $\mathrm{X}$ & & \\
\hline $\mathrm{O}$ & Elogio a la Natividad de Nuestra Señora & $\mathrm{X}$ & $\mathrm{X}$ & & \\
\hline M & Encomio a Nuestra Señora del Socorro & $\mathrm{X}$ & $\mathrm{X}$ & & \\
\hline I & Encomio a la Natividad de Nuestra Señora & $\mathrm{X}$ & $\mathrm{X}$ & & \\
\hline Á & A Nuestra Señora del Socorro & $\mathrm{X}$ & $\mathrm{X}$ & & \\
\hline $\mathrm{S}$ & Elogio al Señor y a San Antonio & $\mathrm{X}$ & $\mathrm{X}$ & & \\
\hline $\mathrm{T}$ & Canción a Nuestra Señora de Guadalupe & $\mathrm{X}$ & $\mathrm{X}$ & $\mathrm{X}$ & \\
\hline I & Versos al patriarca San Joseph & $\mathrm{X}$ & $\mathrm{X}$ & & \\
\hline C & Encomio al Santísimo Rosario & $\mathrm{X}$ & $\mathrm{X}$ & & \\
\hline \multirow[t]{3}{*}{$\mathrm{O}$} & Jácara para corregir a un hijo mío & $\mathrm{X}$ & $\mathrm{X}$ & & \\
\hline & Loa satírica en una comedia & $\mathrm{X}$ & $\mathrm{X}$ & & $\mathrm{X}$ \\
\hline & El portento mexicano (comedia) & & $\mathrm{X}$ & $\mathrm{X}$ & $\mathrm{X}$ \\
\hline
\end{tabular}


TABLA 2

\begin{tabular}{lcc}
\hline Traducciones - Títulos & Princeton & Paris \\
\hline Interrogatorio para confesar indios mexicanos (bilingüe) & $\mathrm{X}$ & $\mathrm{X}$ \\
Práctica para ayudar a bien morir & $\mathrm{X}$ & $\mathrm{X}$ \\
Festivo día del alma & $\mathrm{X}$ & $\mathrm{X}$ \\
Cap. 1 al Sacro Sancto nombre de Dios & $\mathrm{X}$ & \\
Ofrecimiento del Rosario (bilingüe) & $\mathrm{X}$ & $\mathrm{X}$ \\
El texto de la Doctrina & $\mathrm{X}$ & \\
Oración al Spíritu Santo & $\mathrm{X}$ & \\
Conceptos políticos y muy útiles & $\mathrm{X}$ & \\
Pater de Celis Deus, miserere nobis & $\mathrm{X}$ & \\
\hline
\end{tabular}

Al contenido de estas dos tablas hay que añadir las referencias a ciertos escritos suyos que siguen en paradero desconocido. De su obra teatral nos falta:

- Un Encomio al Santísimo Sacramento.

- La Adoración a la Santísima Trinidad.

- Dos Loas a Nuestra Señora de Guadalupe en la dedicación de su nuevo templo (posiblemente de 1706).

En cuanto a las traducciones, faltan estas dos:

- El Arte o gramática de Elio Antonio de Nebrija (89ff.).

- La Doctrina o catecismo de Jerónimo de Ripalda (32ff.). Es probable que haya coincidencias parciales con lo contenido en los ff. 200-207 del manuscrito de Princeton.

\section{REFERENCIAS}

Álvarez, José Rogelio (dir.) 1977. Enciclopedia de México, Edit. Enciclopedia de México, México, 12 ts.

Arias de la Canal, Fredo 1998. Las fuentes profanas de "Primero sueño" y otros ensayos sorjuanistas, Frente de Afirmación Hispanista, México.

Arias-Larreta, Abraham 1976. Literaturas aborígenes de América, $10^{\mathrm{a}}$ ed., Editorial Indoamérica, San José de Costa Rica.

Arrom, José JuAn 1967. Historia del teatro hispanoamericano. (Época colonial), $2^{a}$ ed., Andrea, México.

BAllinger, Rex EDWARD 1951. Los orígenes del teatro español y sus primeras manifestaciones en la Nueva España, tesis, Universidad Nacional Autónoma de México, México.

Beristáin de Souza, José Mariano 1816, 1819, 1821. Biblioteca hispano-americana septentrional, México, 3 ts.

Boban, Eugène 1891. Documents pour servir a l'histoire du Mexique. Catalogue raisonné de la collection de M. E.-Eugène Goupil (Ancienne collection J.M.A. Aubin), Ernest Leroux, Paris, 2 ts. 
Boturini Benaduci, Lorenzo 1746. Idea de una nueva historia general de la América septentrional. Fundada sobre material copioso de figuras, símbolos, caracteres y geroglíficos, cantares y manuscritos de autores indios últimamente descubiertos, Juan de Zúñiga, Madrid, http://bvpb.mcu.es/es/consulta/ registro.cmd? id $=406186$.

BRINCKMANN, BÄRBEL 1969. Quellenkritische Untersuchungen zum mexicanischen Missionsschauspiel (1533-1732), tesis, Universität Hamburg, Hamburg.

Brinckmann, Bärbel 1978. "Coloquios de la Virgen de Guadalupe”, Revista Española de Antropología Americana, 8, pp. 163-170.

Bryant, William C. 1964. "Reaparición de una poesía de Sor Juana Inés de la Cruz, perdida desde 1714", Anuario de Letras, 4, pp. 277-285.

Burkhart, Louise M. 2006. "Juan Diego's World. The representation of social relations in the Guadalupan dramas", en Nahuatl Theater. Our Lady of Guadalupe. Eds. Barry D. Sell, Louise M. Burkhart \& Stafford Poole, University of Oklahoma Press, Norman, t. 2, pp. 31-49.

Cabrera y Quintero, Cayetano 1746. Escudo de armas de México, Viuda de Joseph Bernardo de Hogal, México.

Calleja, Diego 1700. "Aprobación”, en Fama y Obras póstumas del Fénix de México, Décima Musa, poetisa americana, Sor Juana Inés de la Cruz, Manuel Ruiz de Murga, Madrid, ff. III2r-IIIII 4v, http://ds.ub.uni- bielefeld.de/ viewer/ fullscreen/1592397/20/.

Castorena y Ursúa, Juan Ignacio de 1700. "Prólogo", en Fama y Obras póstumas del Fénix de México, Décima Musa, poetisa americana, Sor Juana Inés de la Cruz, Manuel Ruiz de Murga, Madrid, ff. **1r-***2v.

De la Rosa, Augustino 1887. Dissertatio historico-thelogica de apparitione B. M. V. de Guadalupe, Narcisi Parga, Guadalaxarae.

Díaz Cíntora, Salvador 2001. "La loa de Juana Inés" y "Atribuible a la niña Juana Inés Ramírez de Azuaje: Loa satírica" y "Aplaude la fineza que el Señor hizo en quedarse sacramentado con los hombres", Letras Libres, 3, 34, pp. 67-70, 72-75 y 75-78, http://www.letraslibres.com/revista/convivio/ la-loa-de-juana-ines?page $=$ full.

Díaz Cíntora, Salvador 2005. "Yoqui in tlahuépoch Medea, o el náhuatl en la obra de Sor Juana”, en Aproximaciones a Sor Juana. Ed. Sandra Lorenzano, Universidad del Claustro de Sor Juana-Fondo de Cultura Económica, México, pp. 95-100. [Reedición en Memorias de la Academia Mexicana de la Lengua, 30, 2002-2003 (pero en realidad México, 2010), pp. 81-89].

Diccionario Porrúa de historia, biografía y geografía de México 1995. $6^{\mathrm{a}}$ ed., Porrúa, México, 3 ts.

El caballero Lorenzo Boturini. Entre dos mundos y dos historias 2010. Museo de la Basílica de Guadalupe, México.

Escalada, Xavier 1995. Enciclopedia guadalupana, Enciclopedia Guadalupana, México, 4 ts.

Flores, EnRIQue 2007. "Sor Juana y los indios: loas y tocotines", Literatura Mexicana, 18, 2, pp. 39-77, https://revistas-filologicas.unam.mx/ literatura-mexicana/index.php/lm/article/view/ 566/564.

Flores Salinas, Berta 1966. México visto por algunos de sus viajeros (siglo XVIII), Botas, México.

García, Idalia 2009. "Religión y tipografía: la protesta de fe en el impreso novohispano", en Memoria del XXVI Coloquio de Investigación Bibliotecológica y 
sobre la Información. Comps. Filiberto Felipe Martínez Arellano y Juan José Calva González, Universidad Nacional Autónoma de México, México, pp. 215-263, http://www.humanindex.unam.mx/humanindex/consultas/detalle_libros.php?id=11486\&rfc=MAAF530822.

Garibay K., Ángel María 1987 [1953-1954]. Historia de la literatura náhuatl, $3^{\text {a }}$ ed., Porrúa, México, 2 ts.

Glass, John B. 1968. The Boturini collection, Library of Congress, Reference Dept., Hispanic Foundation, Washington. [Ejemplar mecanografiado. Una nota en la página inicial advierte: "Limited reference circulation. Not for publication". Manejo ejemplar de la University of Texas at Austin, Benson Collection. Otra edición, en 1975, Handbook of Middle American Indians. Ed. Howard Cline, vol. 15, Guide to Ethnohistorical Sources, parte 4, University of Texas Press, Austin, pp. 473-486].

González Acosta, Alejandro en prensa. "Dos manuscritos en náhuatl de la primera mitad del siglo XvI".

GoupiL, Eugène 1899. Catalogue de la Bibliothèque Américaine de feu M. E. Eugène Goupil. Livres anciens imprimés au Mexique, ouvrages ayant trait à l'histoire, à l'ethnographie et à la linguistique de diverses contrées de l’Amérique, Paul et Fils et Guillemin, Paris.

Granados y Gálvez, Joseph JoaQuín 1778. Tardes americanas, Felipe de Zúñiga y Ontiveros, México.

Guridi, José Miguel 1820. Apología de la aparición de Nuestra Señora de Guadalupe de Méjico, Alejandro Valdés, Méjico.

Jiménez Moreno, Wigberto 1939. La "Colección Troncoso" de fotocopias de manuscritos, México. [Va también como apéndice 3 al libro de Silvio Zavala 1938].

Juana InÉs de la Cruz, sor 1692. Segundo volumen de las obras de soror Juana Inés de la Cruz, Tomás López de Haro, Sevilla.

Juana Inés de la Cruz, sor 1693. Segundo tomo de las obras de Soror Juana Inés de la Cruz, Joseph Llopis, Barcelona.

Juana Inés de la Cruz, sor 1700. Fama y Obras póstumas del Fénix de México, Décima Musa, poetisa americana, Sor Juana Inés de la Cruz, Manuel Ruiz de Murga, Madrid.

Loera Chávez y Peniche, Margarita 2011. Flor de volcanes. Sor Juana Inés de la Cruz: vida y obra en la región donde nació, Instituto Nacional de Antropología e Historia, México.

Loera Chávez y Peniche, Margarita 2013. "Fuentes históricas virreinales para el estudio del ritual de alta montaña en el Iztaccíhuatl y el Popocatépetl”, Expresión Antropológica, 46/47, pp. 88-112.

López, Patricio Antonio 1925. "Inventario de los documentos recogidos a don Lorenzo Boturini por orden del gobierno virreinal”, Anales del Museo Nacional de México, 3, pp. 1-55.

Martínez López, EnriQue 1968. "Sor Juana Inés de la Cruz en Portugal: un desconocido homenaje y versos anónimos", Revista de Literatura, 33, 65/66, pp. 53-84.

Martínez Marín, Carlos 1994. "Los códices mexicanos de época colonial. Coleccionismo y éxodo", en México en el mundo de las colecciones de arte, Gobierno de la República, México, t. 3, pp. 10-72. 
Olavarría y Ferrari, Enrique de 1895. Reseña histórica del teatro en México, $2^{\mathrm{a}}$ ed., La Europea, México, 3 ts.

Omont, Henri A. 1899. Catalogue des manuscrits mexicains de la Bibliothèque Nationale, Émille Bouillon, Paris.

Palomera, Esteban J. 1988. Fray Diego Valdés, O.F.M. Evangelizador humanista de la Nueva España. El hombre, su época y su obra, Universidad Iberoamericana, México.

Peñafiel, Antonio 1890. Monumentos del arte mexicano antiguo, A. Asher, Berlin, 3 ts.

Poole, StAFford 1995. Our Lady of Guadalupe. The Origins and sources of a Mexican national symbol, 1531-1797, The University of Arizona Press, Tucson-London.

Poole, Stafford 2006. "Introduction. The Virgin of Guadalupe in two Nahuatl dramas", en Nahuatl theater. Our Lady of Guadalupe. Eds. Barry D. Sell, Louise M. Burkhart \& Stafford Poole, University of Oklahoma Press, Norman, t. 2, pp. 3-29.

Poot Herrera, Sara 2003. "Hay loas que no hacen ruido. La hipotética loa infantil de Sor Juana", en Nictimene... sacrílega. Estudios coloniales en homenaje a Georgina Sabat-Rivers. Coords. Mabel Moraña y Yolanda MartínezSan Miguel, Universidad del Claustro de Sor Juana, México, pp. 299-330.

Poot Herrera, SAra 2005. "Sobre una loa atribuida a la niña Juana”, en A proximaciones a Sor Juana. Ed. Sandra Lorenzano, Universidad del Claustro de Sor Juana-Fondo de Cultura Económica, México, pp. 285-298.

Poot Herrera, SAra 2007. "Sobre las pistas de la supuesta loa de Sor Juana", en Simulacros de la fantasía. Nuevas indagaciones sobre arte y literatura virreinales. Homenaje a José Pascual Buxó. Coord. Enrique Ballón Aguirre, Universidad Nacional Autónoma de México, México, pp. 151-170.

Poot Herrera, Sara 2009. "El Mercurio encomiástico, una compilación de festejos religiosos novohispanos en náhuatl y en español”, en Dramaturgia y espectáculo teatral en la época de los Austrias. Ed. Judith Farré, Iberoamericana, Madrid, pp. 203-216.

Poot Herrera, Sara 2009a. "Joseph Antonio Pérez de la Fuente, vecino y paisano de Sor Juana", en Unidad y sentido de la literatura novohispana. Ed. José Pascual Buxó, Universidad Nacional Autónoma de México, México, pp. 359-380.

SACHSE, Frauke 2009. "Documentación de diccionarios y gramáticas k'ichee' del período colonial”, http://www.famsi.org/reports/06009es/.

Sandoval Aguilar, Zazil 1991. Catálogo de manuscritos e impresos en lenguas indígenas de México, de la Biblioteca Nacional de Antropología e Historia (México, D.F.), CIESAS-Instituto Nacional Indigenista, México.

Schmidhuber de la Mora, Guillermo 1990. "La segunda Celestina": una comedia perdida de Sor Juana, Vuelta, México.

Schmidhuber de la Mora, Guillermo 1999. Sor Juana y "El Zurriago", Gobierno del Estado de Colima, México.

Schmidhuber de la Mora, Guillermo 2013. De Juana Inés de Asuaje a Juana Inés de la Cruz. El libro de profesiones del convento de San Jerónimo de México, Instituto Mexiquense de Cultura, México.

Segala, Amos 1989. Histoire de la litterature nahuatl (sources, identités, représentations), Bulzoni, Roma. 
Sell, Barry D. \& Louise M. Burkhart (eds.) 2004-2009. Nahuatl theater, University of Oklahoma Press, Norman, 4 ts.

Sepúlveda y Herrera, María Teresa 1992. Catálogo de la Colección de Documentos Históricos de Faustino Galicia Chimalpopoca, Instituto Nacional de Antropología e Historia, México.

Sepúlveda y Herrera, María Teresa 1999. Manuscritos en lenguas indigenas en los acervos de la Biblioteca Nacional de Antropología e Historia, Instituto Nacional de Antropología e Historia, México.

Serrano Migallón, Fernando 2006. "Señas de identidad. Discurso de ingreso a la Academia Mexicana de la Lengua”, Revista del Posgrado en Derecho de la UNAM, 2, 3, pp. 1-25, https://revistas-colaboracion. juridicas.unam.mx/index.php/rev-posgrado-derecho/article/view/ $17126 / 15335$.

Soriano Vallés, Alejandro 2010. Sor Juana Inés de la Cruz. Doncella del verbo, Garabatos, Hermosillo.

Sten, María y Germán Viveros (coords.) 2004. Teatro náhuatl. II: Selección y estudio crítico de los materiales de Fernando Horcasitas, Universidad Nacional Autónoma de México, México.

Trabulse, Elías 1999. La muerte de Sor Juana, Condumex, México.

Vallejo Villa, Augusto 2001. "Acerca de la loa", Letras Libres, 3, 34, pp. 80-81 y 119, http://www.letraslibres.com/mexico/acerca-la-loa.

Vallejo Villa, Augusto 2005. "El acta de bautizo de Inés, hija de la Iglesia de la parroquia de San Vicente Ferrer de Chimalhuacán”, en Aproximaciones a Sor Juana. Ed. Sandra Lorenzano, Universidad del Claustro de Sor Juana-Fondo de Cultura Económica, México, pp. 381-386.

Vera, Fortino Hipólito 1889. Tesoro guadalupano. Noticia de los libros, documentos, inscripciones, etc., que tratan, mencionan o aluden a la aparición y devoción de Nuestra Señora de Guadalupe, Colegio Católico, Amecameca.

Zavala, Silvio 1938. Francisco del Paso y Troncoso: su misión en Europa, 18921916, Museo Nacional-Departamento Autónomo de Prensa y Publicidad, México.

Zugasti, Miguel 2008. "Teatro recuperado en Charcas: dos loas olvidadas de fray Juan de la Torre (OSA) a la entrada del virrey Diego Morcillo en Potosí, 1716”, en El teatro en la Hispanoamérica colonial. Eds. Ignacio Arellano y José Antonio Rodríguez Garrido, Universidad de NavarraIberoamericana-Vervuert, Madrid-Frankfurt/M., pp. 295-321. 